\title{
Drawing Boundaries for Air Quality Control Under the Clean Air Act: The Importance of NOT Being Nonattainment
}

\author{
William V. Luneburg*
}

TABle of Contents

I. Introduction . . . . . . . . . . . . . . . . . . . 62

II. Regulatory Requirements for Nonattainment Areas . . . 64

III. $\quad$ PM $_{2.5}$ Pollution and Southwestern Pennsylvania $\ldots \ldots .67$

IV. Section 107 of the Clean Air Act and EPA Boundary

GuIDANCE ............................. 68

A. Boundary Guidance Provided by the Clean Air ACT . . . 68

B. Boundary Guidance PRovided by the EPA ......... 71

C. Nonattainment Boundary Drawing and the Problem of

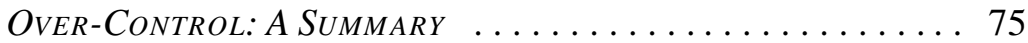

D. Case Law Pertaining to Boundary Determinations .... 77

V. Legal Mechanisms to Deal with Long-Range Transport . . 79

VI. The Nonattainment Designation Process and

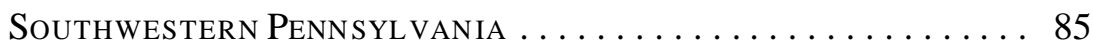

VII. Concluding Observations: The Choices Remaining $\ldots \ldots .98$

* Professor of Law, University of Pittsburgh School of Law. Dr. Roger Westman, Manager of the Air Quality Program of the Allegheny County Health Department, offered valuable comments on an earlier draft of this article. The views expressed herein do not, however, purport to represent those of the Department or Dr. Westman. 


\section{INTRODUCTION}

Much has changed with regard to air pollution control since 1970 when Congress revised the Clean Air Act to assume a form that, in very broad terms, it retains today. From a legal point of view, while states ${ }^{1}$ still retained at that time wide-ranging discretion to design the regulatory controls necessary to attain the air quality goals of the Act, that discretion was significantly limited when Congress revisited the Act in 1977. State discretion diminished to an even greater extent, particularly with regard to the air pollutants ozone, carbon monoxide, and particulate matter, when President George H.W. Bush signed the Clean Air Act Amendments of 1990.

The scientific and technical changes since 1970 have been equally dramatic. Air pollution is no longer viewed as a "local problem," one that threatens only the population located near the sources that produce the emissions. Rather, some of the most dangerous pollutants, ozone and fine particulate matter, form in the atmosphere downwind from the sources of their precursor pollutants and travel hundreds of miles (or more) to adversely impact people's health as well as various aspects of the natural environment including water and forest resources. Moreover, atmospheric models and air quality monitors to identify these pollutants in the ambient air and trace their path from source to receptor have attained a sophistication and general, if not universal, acceptance that was unattainable thirty-six years ago. While the 1977 and 1990 amendments to the Clean Air Act reflected these technical and scientific advances to some extent, the U.S. Environmental Protection Agency, which administers the statute, has been challenged over the last decade to conform a regulatory regime originally intended for dealing with localized air pollution problems to the demands posed by the long-distance, and often transjurisdictional, nature of air pollution as it exists today.

One issue that has, however, been consistently presented since 1970 is the "problem" of potential over-control of emission sources. By "overcontrol," I mean the degree to which emission reductions required of both new and existing sources by a state's plan to attain the National Ambient Air Quality Standards (NAAQS) will result in more control of those sources than necessary to reduce air pollution levels to those specified by the NAAQS.

1. Political subdivisions of states, including counties, may have a significant rolein implementing the CAA. For instance, the Allegheny County Health Department is responsible for design and enforcement of emission reduction measures within Allegheny County, Pennsylvania. 
Whether that result is a "problem" depends significantly on one's point of view. For example, a company required to reduce its emissions by 2000 tons a year when a 1000 reduction would be sufficient to attain the NAAQS would likely contend that the increased costs of control (which rise almost geometrically after a significant amount of emissions are captured or otherwise removed from the production process) serve no purpose; that the benefits of emission control in its case are not justified by the economic costs of that control. ${ }^{2}$ On the other hand, an environmentalist might argue that there is no right to pollute a public resource (the outdoor air we all breathe) and, therefore, a source should eliminate its emissions to the greatest amount technologically feasible. In any event, since the NAAQS are based on evolving science, further research may identify adverse affects below the levels of the NAAQS. ${ }^{3}$ Moreover, given the migration of air pollutants, while control of local sources may not be necessary for improvement in local air quality, there is always an area downwind that will benefit from upwind controls. Accordingly, to this environmentalist, it is not meaningful to talkin terms of "over-control" of sources of pollution.

Without dismissing the environmentalist's arguments, which have much to recommend them, this Article adopts for the purpose of argument the first point of view. This view is generally voiced by local industry, feeling the bite of control measures, and state or local governmental officials, concerned about the prospects for diminished economic growth. Even if economic arguments are afforded too much weight in public policy debates while environmental (and public health) costs and benefits are undervalued, in the practical world in which we all live there is some merit to the position that at least some ground has to be conceded to the other side if environmentalists' arguments are to have a significant impact in shaping the regulatory system.

The issue of over-control as it relates to attainment of the NAAQS has many aspects. The one of immediate concern involves the drawing of those geographical lines that comprise the boundaries of areas within which certain important regulatory controls must, as a matter of Clean Air Act mandate, be implemented. At least since 1977, those legal boundaries have provoked controversy at the local, state, and interstate levels, and, not surprisingly, litigation in the federal courts. What pollution control obligations follow from the drawing of the relevant boundaries? More importantly, what

2. See, e.g., Bruce A. Ackerman \& Richard B. Stewart, Reforming Environmental Law: The Democratic Case for Market Incentives, 13 CoLum. J. ENVTL. L. 171 (1988).

3. See infra note 4. 
considerations may or must be taken into account in the drawing as they relate to potential over-control of local emission sources? Does the EPA have mechanisms aside from boundary demarcation to pinpoint control responsibilities and, in the process, minimize the potential for over-control?

In dealing with these issues, this Article will focus on fine particulate matter (called $\mathrm{PM}_{2.5}$ ) for a variety of reasons: the significance of its harmful health and welfare effects; the magnitude of the effort that has been and will be devoted by the EPA and the states with regard to its control; the degree to which southwestern Pennsylvania has suffered and continues to suffer from this pollutant whose emissions have both a local and trans-jurisdictional component; and the fact that boundary drawing by EPA and the Commonwealth has resulted in an unusual configuration of $\mathrm{PM}_{2.5}$ control areas in and near Allegheny County. In short, a focus on southwestern Pennsylvania and its $\mathrm{PM}_{2.5}$ pollution offers a unique opportunity for insight into the process of boundary drawing, the limitations of that process as a means for dealing with over-control of emission sources, and the currently available mechanisms, if any, to overcome those limitations.

\section{Regulatory Requirements for Nonattainment Areas}

While a full explication of the Clean Air Act (CAA) resembles a "white out" in terms of the dizzying detail that engulfs the reader, for current purposes the principal elements of the regulatory scheme can be rather simply set forth.

The foundation of the regulatory program established by the CAA has been, from the beginning, the attainment and maintenance of the National Ambient Air Quality Standards (NAAQS). Those establish the statutory "goal line" in terms of specific numerical concentrations in the ambient (outdoor) air of pollutants below which concentrations science has not allegedly ${ }^{4}$ identified adverse health and welfare effects. For NAAQS purposes, the EPA moved from regulating "total suspended particulate matter" (TSP) in the 1970s and 1980s, to particulate matter with aerodynamic diameter of ten micrometers or less $\left(\mathrm{PM}_{10}\right)$ into the mid-1990s, and, finally, in 1997, to particulate matter with aerodynamic diameter of 2.5 micrometers or less $\left(\mathrm{PM}_{2.5}\right)$. This focus on increasingly smaller particles was based on the fact

4. What the CAA requires in section 109, 42 U.S.C. $\$ 7409$ (2005), and what happens in practice are different. It is an open secret that NAAQS levels are controlled by nonscientific factors; where science is not clear (as it rarely is on these matters), politics comes into play. 
that the major adverse health effects are generally linked to particles small enough to be inhaled deep into the lungs. Currently, there is a short term (twenty-four hour) standard of sixty-five micrograms per cubic meter $\left(\mathrm{ug} / \mathrm{m}^{3}\right)$ and a long term (annual) standard of fifteen $\mathrm{ug} / \mathrm{m}^{3}$ for $\mathrm{PM}_{2.5}{ }^{5}$

Among the features of the CAA that make it distinctive in the field of federal environmental law are the deadlines (so-called attainment dates) for achieving the level of air quality specified by the NAAQS. ${ }^{6}$ Not only are these deadlines very specific (e.g., December 31, 2010), but serious legal and economic sanctions may attend missing them if the failure is due to inadequate implementation efforts (e.g., increased restrictions on new source growth and cut-offs of federal highway funds to a state). ${ }^{7}$

Moreover, crucial aspects of the regulatory structure created by the CAA derive from Congress's insistence on deadlines for attaining the CAA's air quality goals. Where air quality monitoring or modeling has identified an area of a state as having air quality worse than a NAAQS (known as a nonattainment area), sources of the nonattainment pollutant that are located in that area will have to install what is called "reasonably available control technology"(RACT) or otherwise implement "reasonably available control measures" (RACM) ${ }^{8}$ The emission controls thus imposed on stationary and other sources of the nonattainment pollutant must be implemented no later than such dates as will insure annual reductions in emissions (called "reasonable further progress," attainment is achieved by the established deadline. ${ }^{10}$ As a general matter, the period over which the reductions must occur varies from five to ten years from the date an area has been identified as nonattainment, with more time permitted for areas that are more severely polluted. ${ }^{11}$

5. See 40 C.F.R. $\$ 50.7$ (2005).

6. $\quad 42$ U.S.C. $\$ 7502(a)(2)(2005)$.

7. Id. $\S 7509(\mathrm{a})(4),(\mathrm{b})$.

8. Id. $\$ 7502(\mathrm{c})(1)$. The RACT requirement has in some cases been imposed to require a certain level of emission control regardless of the impact of a source on air quality (for example, in the case of ozone with regard to certain source categ ories covered by EPA's control technique guidelines). See, e.g., 42 U.S.C. \$ 7511(a), (b)(2) (2005). On the otherhand, EPA has also viewed RACT/RACM as synonymous with the level of control necessary to attain the NAAQS, which in some cases may require little or no control on a particular source. For a general discussion of the varying approach to RACT definition, see Proposed Rule to Implement the Fine Particle National Ambient Air Quality Standards, 70 Fed. Reg. 65,984, 66,016, 66,019 (Nov. 1, 2005) (to be codified at 40 C.F.R. pts. 51-52). See, e.g., Sierra Club. v. EPA, 294 F.3d 155, 162 (D.C. Cir. 2002) (upholding the EPA interpretation of RACM).

9. $\quad 42$ U.S.C. $\$ 7501(1)(2005)$.

10. $\quad I d . \S 7502(\mathrm{c})(2)$.

11. Id. $\S 7502(\mathrm{a})(2)(\mathrm{A})$. As a practical matter, since it is the average of air quality readings over 
Early in its administration of the CAA, the EPA encountered the problem of reconciling new source growth in a nonattainment area with the RFP curve, which is based on reductions of emissions from existing sources. Emissions growth in an area could wipe out the progress in emission reduction achieved from existing sources and thereby prevent attainment of the NAAQS by the specified deadline. EPA's solution was ingenious in many ways, though it created one of the most complicated regulatory permit programs found in any environmental statute, one that provoked controversy and resistance from the beginning and remains a fertile ground for dispute at the administrative and judicial levels. In brief, a new major ${ }^{12}$ stationary source of the pollutant for which an area is nonattainment can begin to operate only if: 1) its emissions of that pollutant are no greater than the "lowest achievable emission rate" (LAER) $;{ }^{13}$ and 2) those emissions are at least "offset" by matching reductions in emissions of the same pollutant from existing sources. ${ }^{14}$ It was this "offset" requirement that was designed to maintain the integrity of the RFP curve and thereby protect attainment of the relevant NAAQS on time. These same requirements apply to existing major sources in the area where they are "modified," that is, undergo a physical or operational change that increases by a significant amount the nonattainment pollutant of concern. ${ }^{15}$

In short, if the outdoor air in an area is not as good as one or more of the NAAQS, existing sources in the area will likely have to install expensive technology or institute expensive process changes to reduce their emissions of the nonattainment pollutant over a relatively short period of time. New and modified major stationary sources of the nonattainment pollutant can be built only at the price of installing what will probably be even more expensive technology and also purchasing, or otherwise obtaining from existing sources in the area, emission reductions that are not required by applicable law. A tall order indeed!

To fill out the picture, what happens if an area already meets the NAAQS? Existing sources are off the hook as a general matter; they can keep pumping out their emissions at historic levels. If those sources want to

several years prior to the attainment date that determines if attainment has occurred, a state has less than the full five (or ten) years to implement required controls.

12. The definition of "major" includes, at a minimum, stationary sources having the potential to emit one hundred tons per year. $I d$. $\$ 7602(\mathrm{j})$.

13. Id. $\S \S 7501(3), 7503(\mathrm{a})(2)$.

14. 42 U.S.C. $\$ 7503$ (a)(1), (c) (2005). In many cases more than a one to one offset ratio applies, particularly in seriously polluted areas. See, e.g., id. § 7511a(d) (1.3 to one offset ratio in severe ozone nonattainment areas).

15. Id. $\S \S 7501(4), 7502(\mathrm{c})(5)$. 
increase their emissions and satisfy various annual emission tonnage thresholds ${ }^{16}$ or, on the other hand, new large stationary source ${ }^{17}$ want to begin operation in the area, they are, like major stationary sources in nonattainment areas, subject to technology and other requirements. ${ }^{18}$ But the purpose of the requirements is different from nonattainment areas, it is to minimize the amount of deterioration of the good quality air in the area and downwind in specially protected federal lands (like large national parks) and, in all events, maintain compliance with the NAAQS. However, the controls mandated tend to be less demanding (and thus less expensive) than the LAER and offset requirements, hence the benefits of being a so-called PSD (Prevention of Significant Deterioration) area.

\section{PM $_{2.5}$ Pollution and Southwestern Pennsylvania}

Common constituents of $\mathrm{PM}_{2.5}$, which encompasses both solid and liquid particles, include sulfates, nitrates, ammonium, and organic compounds, some of which may be omitted directly into the ambient air and others of which may form in the atmosphere as a result of various chemical transformations. The gaseous precursors of sulfates and nitrates include sulfur dioxide $\left(\mathrm{SO}_{2}\right)$ and the oxides of nitrogen $\left(\mathrm{NO}_{\mathrm{x}}\right)$ which may be emitted by sources far upwind of the area where they have their primary adverse impact. ${ }^{19}$

The localized and downwind health effects of $\mathrm{PM}_{2.5}$ may be severe indeed: premature mortality; and aggravation of respiratory and cardiovascular disease (including asthma, heart attacks, and cardiac arrhythmia), to name a few. Particularly sensitive to this pollutant are older adults, people with heart and lung diseases, and children. ${ }^{20}$

In determining whether Allegheny and nearby counties met the $\mathrm{PM}_{2.5}$ NAAQS, the EPA and the Commonwealth relied on monitored air quality data for 2001-2003 obtained at various locations. The so-called "design values"

16. Id. $\S 7479$ (1) (a potential to emit of one hundred tons per year or 250 tons per year depending on the type of source).

17. $I d$.

18. Id. §7475. Briefly stated, such sources must install "best available control technology"(BACT) and, if emissions at that level will interfere with the "increments of permissible deterioration" in the area of the source's location or other areas, have adverse impacts on "air quality related values" (e.g. visibility) within Class I (specially protected) areas, or interfere with the attainment or maintenance of the NAAQS, the emissions must be further reduced to avoid those impacts.

19. Proposed Rule to Implement the Fine Particle National Ambient Air Quality Standards, 70 Fed. Reg. 65,984, 65,992-98 (Nov. 1, 2005) (to be codified at 40 C.F.R. pts. 51-52).

20. Id. at 65,988 . 
ranged from a low of $13.1 \mathrm{ug} / \mathrm{m}^{3}$ (South Fayette) to a high of $21.2 \mathrm{ug} / \mathrm{m}^{3}$ (Liberty Borough), ${ }^{21}$ with reference to the annual standard of $15 \mathrm{ug} / \mathrm{m} .{ }^{3}$ The $21.2 \mathrm{ug} / \mathrm{m}^{3}$ design value for $\mathrm{PM}_{2.5}$ was the highest of any area in the Northeast.

\section{Section 107 of the Clean Air Act and EPA Boundary Guidance}

\section{A. Boundary Guidance Provided by the Clean Air Act}

Section 107(a) of the CAA provides:

Each State shall have the primary responsibility for assuring air quality within the entire geographic area comprising such State by submitting an implementation plan for such State which will specify the manner in which national primary and secondary ambient air quality standards will be achieved and maintained within each air quality control region in such State. ${ }^{22}$

This provision reflects the original understanding of the drafters of the CAA that air pollution implicated predominantly local sources of emissions, that is to say, violations of the NAAQS were usually attributable to emission sources located reasonably close to the monitors recording those violations. For instance, in the days when steel was "King," the hilly nature of Allegheny County, which could capture, channel, and hold harmful emissions, particularly during times of air inversions, was a major factor in drawing the boundaries for applicable emission control requirements to encompass areas no more than thirty or so miles from the center of Pittsburgh. Even then, of course, there remained small "islands" within the air quality control region encompassing Allegheny County that avoided high particulate readings because of the isolating effects of topography, prevailing wind direction, and the absence of nearby emission sources.

In 1977, frustrated with the slow pace of control efforts, particularly as they involved pollutants related to fossil-fuel burning (including ozone), Congress introduced a new concept-the nonattainment area, whose boundaries could extend beyond or be drawn within existing air quality control regions. Specifically, Congress directed in section 107(d) of the CAA that, with regard to each state, EPA separately designate (for each NAAQS) the "area(s)" in the state: 1 ) where the monitored or modeled air quality does

21. Letter from Kathleen A. McGinty, Secretary, PA Dep't of Envtl. Prot., to Donald S. Welsh, Regional Administrator, EPA app. I, figs. 3-4 (Aug. 30, 2004) [hereinafter August McGinty Letter], at http://www.dep.state.pa.us/dep/deputate/airwaste/aq/attain/recommendations.htm.

22. 42 U.S.C. $\$ 7407$ (a) (2000) (emphasis added). 
not meet the required NAAQS level ("nonattainment areas"); 2) where data indicate that the NAAQS have been attained ("attainment areas"); and 3) where information is not available to determine whether or not the NAAQS has been attained ${ }^{23}$ ("unclassifiable areas" which, however, are treated as attainment areas for regulatory purposes). ${ }^{24}$ With regard to a nonattainment area, our principal focus of concern, section 107(d) directs that its boundaries encompass "nearby areas" contributing to NAAQS violations. ${ }^{25}$

These nonattainment designations serve at least two important functions. First of all, the designation advises the public at large that the air it is breathing is unhealthy. ${ }^{26}$ Formal notification of that type can be used by particularly vulnerable groups living in the area, e.g., persons suffering from asthma, as a basis on which to take protective measures, e.g., carrying a bronchodilator when outdoors. In addition, the designation, as a warning of possible adverse health effects, may stimulate local political action necessary to support vigorous efforts at pollution reduction. ${ }^{27}$

The second function of the nonattainment designation extends, however, beyond advice to compulsion. The legal effect of the designation is to require within the area RACT/RACM for existing sources of the pollutant for which the NAAQS is not attained and LAER with offsets for major new and modified sources of the nonattainment pollutant. ${ }^{28}$ The practical consequence of this is clear and dramatic — a plant, new or existing, located in an attainment area and close to the border of a nonattainment area escapes the expenses of technology controls and offset requirements applicable, literally, next door. ${ }^{29}$

23. Section $7407(\mathrm{~d})(1)(\mathrm{A})$.

24. Id. $\$ 7471$.

25. Section $7407(\mathrm{~d})(1)(\mathrm{A})(\mathrm{i})$ ("nonattainment, any area that does not meet (or that contributes to ambient air quality in a nearby area that does not meet) the national primary or secondary ambient air quality standard for that pollutant").

26. Fed. Advisory Comm. Act Subcomm. for Ozone, Particulate Matter \& Reg’l Haze Implementation Programs, EPA, Final Report on Subcommittee Discussions 3-4 (1998) [hereinafter 1998 FACA REPORT], available at http://www.epa.gov/ttn/faca/sudirs/finalfac.pdf.

27. As a practical matter, the designations are not nearly as meaningful, on a day-to-day basis, as other information that is widely available. See, e.g., AIRNOW, available at http://airnow.gov/ (last visited Apr. 19, 2006).

28. 42 U.S.C. $§ 7502(c)$ (2000). See text supra notes 12-15.

29. As we will see, there are ways for the EPA to wipe out such artificial boundaries and impose necessary controls. Nevertheless, all of these alternatives, while they expand the boundaries for control, do not eliminate the need to draw boundaries somewhere. As Figure 7 illustrates, for example, sources located or to be located in Butler County within a stone's throw of the border with Armstrong County will be subject to RACT/RACM or LAER/offsets, while sources just over the border in Armstrong County will be subject to the less demanding PSD program (Best Available Control Technology, BACT, and air quality impact analysis). 
Obviously, the drawing of the boundaries of nonattainment areas is of major economic and political concern since states and local governments view that designation as an incentive for local industries to move out and a disincentive for others to move in.

Section 107(d) offers some guidance on how nonattainment boundaries should be drawn. For seriously polluted carbon monoxide and ozone areas, the presumptive boundaries for nonattainment areas include entire metropolitan statistical areas (MSAs) and consolidated metropolitan statistical areas (CMSAs) which contain identified NAAQS violations. ${ }^{30}$ Where a state can demonstrate that sources in a portion of that broadened area do not "contribute significantly" to NAAQS violations, the EPA can exclude from the designated nonattainment area the portion of the MSA or CMSA encompassing those sources. ${ }^{31}$ In making the determinations to cut up MSAs and CMSAs into attainment and nonattainment areas, section 107(d) directs the EPA to consider, among other factors, "population density, traffic congestion, commercial development, industrial development, meteorological conditions, and pollution transport." 32

While section 107(c) authorizes the EPA to designate an interstate air quality control region to include portions of more than one state, ${ }^{33}$ there is no express EPA authority to designate an interstate "nonattainment area" as a single entity. So what happens, for example, if the nonattainment status of an area is due in part to a source upwind but located in another state? Will the upwind source escape the RACT, LAER, and offset requirements? Not necessarily.

If the upwind emission-generating activity is located "nearby" (a term not defined in the CAA) an area where NAAQS violations have been identified, the statutory definition of nonattainment area, which includes areas "nearby" that are sources of nonattainment, ${ }^{34}$ requires the EPA to designate the portion of the state containing the upwind emission source as nonattainment. That is true even if there is no NAAQS exceedance at the source's location as long as that upwind source contributes in any degree to the nonattainment status of the area located in the other state; a "significant" contribution is not legally required. ${ }^{35}$

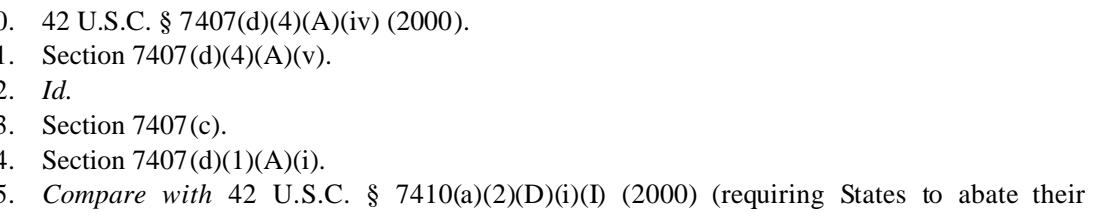


Secondly, though section 107(d) does not expressly say so, the presumptive nonattainment boundaries of a MSA and CMSA with regard to ozone and carbon monoxide include any areas within those boundaries, whether or not they are within the same state. An example would be the Philadelphia (Pa)-Camden (NJ)-Wilmington (Del) MSA.

\section{B. Boundary Guidance Provided by the EPA}

As with all other aspects of the CAA, the EPA has elaborated on section 107 through the issuance of guidance documents. On April 1, 2003, it did so with regard to drawing boundaries for $\mathrm{PM}_{2.5}$ nonattainment areas which EPA planned to designate (and did designate) in December 2004, based on air quality monitoring data from the 2001-2003 calendar years. ${ }^{36}$ That guidance reflected an approach similar to that used for EPA's section 107(d) designations for the eight hour ozone standard. ${ }^{37}$

Consistent with the section 107(d) definition of nonattainment area, the EPA noted in its $\mathrm{PM}_{2.5}$ guidance:

Thus, a key factor in setting boundaries ... is determining the geographic extent of nearby source areas contributing to the nonattainment problem. For each monitor or group of monitors that exceed a standard, nonattainment boundaries must be set that include a sufficiently large area to include both the area judged to violate the standard and the source areas that contribute to these violations. ${ }^{38}$

Evidence indicated that violations of the $\mathrm{PM}_{2.5}$ standard could be attributable to both local sources and long-range transport of the pollutant or its precursors. ${ }^{39}$ At the same time, with regard to urban areas, the Agency "found an association of higher $\mathrm{PM}_{2.5}$ concentrations with greater levels of urban activity," attributable to, for instance, motor vehicle use, home heating, and industrial activities. ${ }^{40}$ Therefore, the EPA adopted the approach mandated

"significant" contributions to nonattainment in other States), discussed in text infra notes 84-86. But see note 51 infra.

36. See Memorandum from Jeffrey R. Holmstead, Assistant Administrator, EPA, to Regional Administrators, EPA (Apr. 1, 2003), at http://www.epa.gov/pmdesignations/documents/ pm25_desig_guidance_final.pdf.

37. See Memorandum from John S. Seitz, Director, Office of Air Quality Planning \& Standards, EPA, to Regional Air Directors, EPA (Mar. 28, 2000), at http://www.epa.gov/ozonedesignations/ documents/032800_boundaryguidance.pdf.

38. Memorandum from Jeffrey R. Holmstead, supra note 36, at attachment 2 at 4.

39. Id.

40. Id. at attachment 2 at 5 . 
by the CAA only in the case of ozone and carbon monoxide ${ }^{41}$ and determined that presumptive $\mathrm{PM}_{2.5}$ boundaries for urban areas with monitored NAAQS violations would extend to the limits of the entire MSA, or, in metropolitan areas consisting of multiple MSAs, to the entire CMSA. ${ }^{42}$ This would insure, according to the EPA, that all potential sources of the nonattainment monitored within the area would be included. ${ }^{43}$

EPA also indicated that, in some cases, even these urban boundaries might be expanded further to include "nearby" sources contributing to the urban nonattainment. ${ }^{44}$ On the other hand, since $\mathrm{PM}_{2.5}$ nonattainment could arise solely from certain local sources, nonattainment boundaries in urban areas might, in some cases, be more tightly drawn. It noted, for example, that "violations can be caused by the emissions from a single major source or set of sources, in some cases exacerbated by severely restricted atmospheric dispersion (such as a narrow mountain valley)." ${ }^{45}$

With regard to "rural areas," those recording a NAAQS violation and adjacent to an urban area itself monitoring a NAAQS exceedance would generally be combined with the next door urban area. ${ }^{46}$ Outside these rural areas, the EPA adopted the presumption that, if a monitor located in a county showed a $\mathrm{PM}_{2.5}$ exceedance, the entire county was presumptively nonattainment. ${ }^{47}$ As in the case of urban areas, the EPA indicated that those boundaries could be expanded to include other contributing areas or, alternatively, only part of a county might be designated nonattainment depending on the location of the source or sources of the air quality problem. ${ }^{48}$ However, if a state wanted to divide a county into attainment and

41. See text supra note 30 .

42. Memorandum from Jeffrey R. Holmstead, supra note 36, at attachment 2 at 5. The Office of Management and Budget later revised urban area definitions on June 6, 2003 to establish core-based statistical areas (CBSAs) (comprised of metropolitan and micropolitan areas) and combined statistical areas (CSAs) (comprised of two or more core-based statistical areas). While EPA did not revise its urban boundary presumptions to adopt these revisions, it directed the states to take these revisions into account in drawing boundary lines. See Memorandum from Lydia N. Wegman, Director, Air Quality Strategies and Standards Division, to Regional Air Division Directors (Feb. 13, 2004), at http://www.epa.gov/pmdesignations/documents/PM25desigs-2003defsv2.pdf.

43. Memorandum from Jeffrey R. Holmstead, supra note 36, at attachment 2 at 5.

44. Id. at attachment 2 at 4, 6-7.

45. Id. at attachment 2 at 6 . While the description in the text might, on first glance, bring to mind the Clairton Coke Works of US Steel, as we will see, text infra notes 126-33, in that instance PM $_{2.5}$ bound aries were not drawn to divide an urban area into attainment and nonattainment portions but, rather, into two separate nonattainment areas, one surrounded by another.

46. Memorandum from Jeffrey R. Holmstead, supra note 36, at attachment 2 at 8.

47. $I d$.

48. Id. 
nonattainment portions, it would have to demonstrate ("provide convincing evidence") that the monitor showing an exceedance was not representative of the entire county, that sources in the proposed-to-be-excluded portion were not contributing to the monitored exceedance, and that the air in that portion met the NAAQS. ${ }^{49}$ That showing was similar to the one required to limit nonattainment boundaries within an urban area. ${ }^{50}$

EPA listed the factors it would consider in departing from the presumptive urban and rural boundaries, either in the direction of greater or lesser inclusiveness. Those factors were:

! Emissions in areas potentially included versus excluded from the nonattainment area

! Air quality in potentially included versus excluded areas

! Population density and degree of urbanization, including commercial development in included versus excluded areas

! Traffic and commuting patterns

! Expected growth (including the extent, pattern and rate of growth)

! Meteorology (weather/transport patterns)

! Geography/topography (mountain ranges or other air basin boundaries)

! Jurisdictional boundaries (e.g. counties, air districts, Reservations, etc.)

! Level of control of emission sources ${ }^{51}$

With regard to monitored nonattainment in a metropolitan area encompassing more than one state, the EPA adopted a "strong presumption" that the entire MSA or CMSA would be designated as one nonattainment area. $^{52}$ This was clearly dictated by the assumption underlying its approach to drawing urban boundaries generally, that is to say, the likely contribution

\section{Id.}

50. Id. at attachment 2 at 7 .

51. Id. Section 107 (d) could be read literally to require the inclusion of a source in a nonattainment area if any portion of its emissions, together with the emissions from other sources, increased the concentration of the pollutant of concern above the NAAQS level. But such an interpretation would read equitable considerations entirely out of section 107(d). For example, assume the emissions of one very well-controlled source in state A, along with the emissions from an entirely uncontrolled source in state B, create a violation of the NAAQS in state B, but state A's source contributes only five percent of the emissions of concern in state B and had state B imposed even a moderate level of control on its source, the NAAQS would be attained without any additional control being required of state $A$. In these circumstances, there is a strong argument from an equitable point of view that state A's source should not be deemed to be a contributor to the nonattainment in state B. It is this type of situation which is accounted for by the ninth factor in EPA's list and may arise in both interstate and intrastate contexts.

52. Id. at attachment 2 at 8 . 
of many sources throughout the urban area to a monitored NAAQS exceedance. Unlike the case of ozone and carbon monoxide, where the CAA itself created the urban area presumptive boundaries, there is no similar provision in section 107 with regard to particulate matter. However, the EPA could rely on the fact that section 107(d)'s mandate to include "nearby" contributing sources authorizes it to designate an area outside one state as nonattainment if it contributes to nonattainment in another state.

Given the fact, however, that atmospheric transport of $\mathrm{PM}_{2.5}$ and its precursors to cause violations of the NAAQS routinely occurs not just within the boundaries of MSAs and CMSAs, but over hundreds of miles, how far does section 107(d)'s mandate to include "nearby" contributing sources in nonattainment designations extend? The EPA's $\mathrm{PM}_{2.5}$ guidance does not address that question, but its ozone boundary guidance does and rejects an expansive definition of section 107(d) as including long-range transport, which, EPA found could be, and was being, dealt with through other statutory mechanisms ${ }^{53}$ which are discussed below.

While the EPA does not offer an explanation for this interpretation, the difficulties with reading section 107(d)'s reference to "nearby" too broadly are readily apparent. If, for example, a significant source of Pittsburgh's $\mathrm{PM}_{2.5}$ nonattainment were located, for example, in Columbus, Ohio, an expansive interpretation of the statutory language could mean that the entire geographical area from Columbus to Pittsburgh would be designated nonattainment and subject to RACT, LAER, and offset requirements. That might level the economic playing field, avoiding the competitive economic disadvantages that flow from a nonattainment area limited to the area of Pennsylvania around Pittsburgh. But that result would follow, arguably, at a significant economic cost ${ }^{54}$ that might not be justified to the extent that many existing and new sources of $\mathrm{PM}_{2.5}$ and its precursors would have to limit their emissions while not contributing much, if at all, to nonattainment in the Pittsburgh area. ${ }^{55}$ The obvious way to avoid that consequence of a broad

53. Memorandum from John S. Seitz, supra note 37, at attachment at 6.

54. To establish exactly what those costs would be, however, would be a major undertaking. To the extent that RACT/RACM is determined, in part, by the amount of emission reduction deemed necessary to attain the NAAQS, its calculation may vary depending on the circumstances of individual sources. Since it is impossible to know a priori how many new major stationary sources might be built in an area or how many major stationary sources will be modified, the costs of their control (including the purchase of offsets) is similarly speculative. Moreover, the costs would have to include to some degree the economic losses attributable to the failure of stationary sources to locate in the area based on the nonattainment determination.

55. Even if it could be established that RACT reductions from existing sources in this broadened 
nonattainment designation would be to cut up the area into islands of nonattainment and attainment depending on detailed showings by Ohio and Pennsylvania with regard to the likely contribution of existing sources to nonattainment in Pittsburgh. ${ }^{56}$ Putting that type of burden either on the states or EPA would, at a minimum, impose significant resource costs and create huge delays for NAAQS implementation. And, in any event, given the limits of air quality modeling, it would be unlikely that the islands of "nonattainment" would be so small as to include only the "footprint" of existing sources rather than a much broader area, such as a county or collection of contiguous counties. In that event, the problem of over-control would still be present.

\section{Nonattainment Boundary Drawing and the Problem of Over-Control: A Summary}

Since designation of an area as nonattainment has the legal effect of imposing on the entire area RACT, LAER, and offset requirements, there is the possibility, or certainty in many cases, that some sources will be subject to controls that are not necessary for the attainment and maintenance of the NAAQS within the area or in other areas. ${ }^{57}$

area would reduce air quality concentrations of the pollutant of concern in the downwind nonattainment area and that emission offsets from new and modified major sources in this broadened area would maintain the RFP curve downwind, the LAER requirement by itself would not contribute to attainment downwind. This is because, where it applies, compliance with LAER is a requirement that is not itself geared to NAAQS attainment. Rather it is a "price" that must be paid by new or modified sources locating in a covered area where, because of its nonattainment designation, the air is assumed to be unhealthy, although in the case posed in the text, the air quality in the vicinity of the new or modified source may meet the NAAQS. LAER also functions to prevent a large new or modified source from consuming all the available offsets and thus freezing out the building of other new or modified sources. In short, in the case described in the text, the costs imposed by the LAER requirement are the most obvious, and perhaps the most significant, of the over-control costs implicated in dra wing nonattainment area boundaries on aregion-wide basis.

56. It should be noted that the PSD program for attainment areas requires new and modified major sources to make these types of demonstrations, for example, that the new emissions do not interfere with the NAAQS attainment anywhere. But that is done on a case-by-case basis. Moreover, no one would claim that PSD analysis is cheap; some would claim it is ineffective to protect downwind areas because of the limits of accurate modeling analysis.

57. It is crucial to reiterate at this point that, even if an area is designated attainment, under the PSD program increased emissions from new and modified major sources located in that area must be controlled in such a way as to prevent interference with the attainment and maintenance of the NAAQS in any area. However, the PSD program is not, as a general matter, as demanding as the nonattainment requirements in terms of required controls and offsets. See text supra notes 16-18. 
Theoretically, of course, it might be possible in some instances to limit a nonattainment area to the location of the monitored violation of the NAAQS and a close-by source or sources identified as the sole contributors to that violation. In that case, the problem of over-control vanishes for all intents and purposes. However, given the nature of PM and other pollution, such scenarios are comparatively rare. More likely is the case that the monitored violation is attributable to many large and small sources scattered over a much broader area - this is the scenario the EPA accepts as the normal situation for at least ozone and $\mathrm{PM}_{2.5}$. In conjunction with section 107(d)'s direction to include "nearby" sources contributing to nonattainment (though the NAAQS may not exceed the standard at their location), this normal scenario underlies EPA's presumption in favor of MSA and CMSA boundaries for urban nonattainment areas and in favor of entire counties for rural nonattainment areas. $^{58}$ To overcome those presumptions and define nonattainment boundaries more narrowly requires not only sizable resources in terms of time, money, and personnel, but also demands the development or identification of models or other methodologies that offer more than just possible explanations but convincing ones (EPA refers to "convincing evidence"). This is no short order and, regardless of relatively isolated instances here and there, it would be unreasonable to expect that boundaries of nonattainment areas will be drawn as narrowly as possible and, thereby, avoid significant over-control. On the other hand, the EPA's narrow interpretation of "nearby" avoids the risk of the substantial over-control that would be caused by drawing the boundaries of nonattainment based on long-range transport to include not only the areas of monitored violations, but also the areas where the sources of the pollutants or their precursors originate. At the same time, the EPA accepts that there is often a long-range component to nonattainment in urban and rural areas, but it has proceeded to deal with that through statutory mechanisms outside section 107. As we will see, those approaches have the potential of limiting, though not eliminating, the problem of over-control with regard to pollutants like $\mathrm{PM}_{2.5}$. They do so by identifying upwind source areas responsible to a substantial degree for downwind pollution and placing at least part of the burden of reduction on them, thereby relieving some, though

58. With regard to nearby sources outside of MSAs and CMSAs or counties, but possibly contributing to nonattainment within the MSA, CMSA or county, the EPA guidance does not formally adopt any particular presumptions other than where an area adjoining an MSA or CMSA contains a monitor indicating an exceedance of the NAAQS, in which case inclusion is presumed. See Memorandum from Jeffrey R. Holmstead, supra note 36, at attachment 2 at 8. 
perhaps not all, of the emission reduction obligations for the sources in nonattainment areas.

\section{Case Law Pertaining to Boundary Determinations}

Given the crucial significance of drawing nonattainment area boundaries in terms of applicable regulatory controls and the competitive disadvantages thereby created $v i s-a$-vis attainment areas, it is not surprising that litigation challenging EPA designations has been common.

In Western Oil \& Gas Ass'n v. EPA ${ }^{59}$ petitioners challenged ozone nonattainment designations in the San Francisco Bay area that included upwind areas where air quality allegedly met the applicable NAAQS and large oil and gas refineries whose emissions were blown into areas to the south and east where NAAQS violations were identified. The Ninth Circuit Court of Appeals panel upheld the EPA's designations despite the fact that the term "nonattainment area" was at the time of this case statutorily defined to include areas where monitoring or modeling showed a violation of the NAAQS. The EPA argued that if it failed to include the upwind sources in the nonattainment area "the possible over-control of sources within the designated nonattainment area and the probable under-control of sources outside of the area could result in an economically and technically unreasonable strategy and continued NAAQS violations." ${ }^{60}$ The State concurred and the court found the purported rationale "common sense." 61 Section 107(d)'s inclusion of "nearby" contributing areas in nonattainment designations, added in 1990, eliminates the need to stretch the statutory language to achieve this result today.

In Ohio v. Ruckelshaus ${ }^{62}$ a panel of the Sixth Circuit Court of Appeals arrived at the same conclusion in a case where the EPA refused to redesignate as attainment a county in Ohio where the air quality met the ozone NAAQS but the pollutants migrated to Cleveland, contributing to its violation of the NAAQS. ${ }^{63}$

Two court of appeals' decisions dealing with designations focused on the nonattainment status of southwestern Pennsylvania for EPA's old one hour

59. 767 F.2d 603 (9th Cir. 1985).

60. Id. at 606-07.

61. Id. at 607 .

62. 776 F.2d 1333 (6th Cir. 1985).

63. But see Ill. State Chamber of Commerce v. EPA, 775 F.2d 1141 (7th Cir. 1985) (vacating the EPA's refusal to re-designate to attainment various counties outside Chicago that monitored no NAAQS violations but contributed to downwind nonattainment on the basis of EPA's failure adequately to explain its action). 
ozone standard. ${ }^{64}$ First, in Southwestern Pennsylvania Growth Alliance v. Browner $^{65}$ (SPGA I), Judge (now Justice) Alito for a Third Circuit panel rejected a challenge to an EPA decision to maintain the ozone nonattainment status of the Pittsburgh-Beaver Valley Area. The petitioner alleged that much of the ozone originated outside the area. The EPA not only contested that factual premise, but argued that, even if it were true, the Clean Air Act required that the nonattainment status be maintained because existing air quality data showed continued violation of the ozone NAAQS in southwestern Pennsylvania; in those circumstances section $107(\mathrm{~d})$ purportedly required a designation of nonattainment. ${ }^{66}$ The court deferred to both EPA's technical and legal determinations. ${ }^{67}$ In his concurrence, Judge Becker noted the apparent unfairness of saddling the Pittsburgh area with control requirements given the transport of pollutants from outside the state. ${ }^{68}$

The same petitioner from SPGA I then challenged the EPA's approach with regard to the upwind area where at least some of the ozone or its precursors originated. In Southwestern Pennsylvania Growth Alliance v. Browner $^{69}$ (SPGA II), it directed its attack at EPA's re-designation of the Cleveland-Akron-Lorain Ohio Area to attainment when, the petitioners alleged, Pittsburgh continued to suffer from the downwind effects of the Ohio ozone in terms of its nonattainment status, including the economic disadvantages flowing therefrom..$^{70}$ Again the petitioners were rebuffed, this time based on EPA's plans to address the transport issue, not by means of the designation/re-designation process, but through requiring states upwind of Pennsylvania to institute more stringent controls to reduce downwind ozone impacts, ${ }^{71}$ an approach which will be considered below.

Finally, in Pennsylvania Department of Environmental Protection v. $E P A,{ }^{72}$ Pennsylvania and Delaware challenged the EPA's determination of nonattainment boundaries for its new eight-hour ozone standard, which was adopted in 1997. In part, the suit contended that the EPA's placement of one

64. References to the "one-hour" ozone standard refer to the one which required averaged ozone readings at a monitor over a one hour period, as opposed the new, currently effective, "eight-hour" ozone standard which provides for eight hour averages of monitor readings.

65. 121 F.3d 106 (3d Cir. 1997)

66. Id. at $115-16$.

67. Id. at $117-18$.

68. Id. at $124-25$.

69. 144 F.3d 984 (6th Cir. 1998).

70. Id. at 988 .

71. Id. at $989-90$.

72. 429 F.3d 1125 (D.C. Cir. 2005). 
New Jersey county and one Maryland county in the Philadelphia nonattainment area was improper in light of alleged downwind pollutant effects. The court did not upset the EPA's determination since it was consistent with its ozone boundary guidance. ${ }^{73}$ Delaware launched a broader challenge, asserting that the EPA should have created one region-wide nonattainment area including both mid-Atlantic and northeastern states whose emissions impacted on one another's ability to attain the NAAQS. In rejecting this contention, the court accepted the EPA's interpretation of "nearby" to exclude long-range transport as a basis for drawing the boundaries of nonattainment areas. ${ }^{74}$

In short, the case law to date has supported the EPA's general approaches to nonattainment boundary determinations, including both the expansion of nonattainment areas to include contributing "nearby" sources and the refusal to extend boundaries to reflect long-range transport of pollutants and their precursors.

\section{Legal Mechanisms to Deal with Long-Range Transport}

The EPA's initiatives since the mid-1990s to come to grips with the longrange transport of pollutants and their precursors in the context of the program to attain the NAAQS have represented one of the Agency's most innovative and successful air quality programs, at least when measured in terms of aggregate tonnage reductions. The legal and technical complexities presented have been formidable indeed, though to date the challenges in the courts have been largely rebuffed. For current purposes, a brief overview is sufficient. ${ }^{75}$

Prior to 1990, while occasionally the EPA was asked to force an upwind state to impose more stringent controls to mitigate downwind transport into another state, the EPA chose not to intervene and its inaction was upheld by the federal courts. ${ }^{76}$ The EPA's unwillingness to act was based on a variety of factors, including the lack of technical resources adequately to trace the transformation of pollutants in the ambient air and their path from source to

73. Id. at 1129.

74. Id. at 1129-30.

75. For a detailed history of these efforts through 2001, see William V. Luneburg, Clean Air Implementation and the Impact of Whitman v. American Trucking Associations, Inc., 63 U. PItT. L. Rev. 1 (2001).

76. See, e.g., New York v. EPA, 852 F.2d 574 (D.C. Cir. 1988); Air Pollution Control Dist. v. EPA, 739 F.2d 1071 (6th Cir. 1984); Connecticut v. EPA, 696 F.2d 147 (2d Cir. 1982). See generally Timothy Talkington, Interstate Air Pollution Abatement and the Clean Air Act Amendments of 1990: Balancing Interests, 62 U. CoLO. L. Rev. 957 (1991). 
receptor. ${ }^{77}$ Politically, the EPA was also put in the difficult position of having to request that economic costs be imposed on one state to benefit the residents of another state; in the circumstances, avoidance appeared to be the best strategy.

In 1990, the Amendments to the CAA reflected increased political will by Congress in coming to grips with long-range transport problems. Evidence of the newly discovered congressional determination was Title IV, creating a nationwide trading program to reduce aggregate levels of sulfur dioxide and, thus, acid rain. ${ }^{78}$ Moreover, the Amendments authorized and, in the case of ozone in the northeast, mandated the creation of transport commissions that would include both states where emissions originated and states where effects were felt, to make recommendations to the EPA with regard to what individual states within the regions should do to reduce their contributions to transboundary pollution. ${ }^{79}$

Not long after the states in the northeast and mid-Atlantic regions began the planning process to adopt the emission control programs (SIPs) required by the 1990 CAA Amendments to attain the one-hour ozone NAAQS, it became apparent both to them and to the EPA that, without upwind reductions in ozone precursors from the mid-west, attainment downwind within the attainment timeframes allowed by the CAA would be impossible. Advocated by the Environmental Council of the States, the Ozone Transport Assessment Group (OTAG) convened in March 1995; it was composed of representatives from the thirty-seven easternmost states, the District of Columbia, the EPA, industry, and environmental organizations. Costing \$20 million and involving hundreds of air quality control professionals, OTAG continued its work over the next two years. ${ }^{80}$ Its efforts identified nitrogen dioxide as the principal ozone precursor of concern for long-range transport and its workgroups conducted state-of-the-art "modeling" runs tracing $\mathrm{NO}_{\mathrm{x}}$ for hundreds of miles to downwind areas. It was on the basis of these technical analyses, later

77. See, e.g., Connecticut v. EPA, 696 F.2d at 165 ("Connecticut and CFE vigorously contend that even if the direct particulate emissions from LILCO's plants will not prevent the attainment of the NAAQSs for TSP in Connecticut, the indirect formation of sulfates will. The possibility does exist that higher sulfur emissions will react with other elements in the atmosphere to create dangerous particulates called sulfates. The short answer to petitioners' contention, however, is that the EPA, as yet, has no adequate model to predict the likelihood of that possibility. See Guideline on Air Quality Models (1978).").

78. 42 U.S.C. $\S \S 7651-76510$ (2005).

79. Id. $\S \S 7506 \mathrm{a}, 7511 \mathrm{c}$.

80. A study of OTAG's work and contributions was prepared for the National Center for Environmental Decision-Making Research and is available at http://www.ncedr.org/casestudies/ otag/index.htm. 
supplemented with its own modeling, that the EPA developed its regulatory strategy that focused first on ozone and, more recently, on $\mathrm{PM}_{2.5}$.

At the same time that the EPA and others were expanding the technical horizons for air quality control, the Agency established, as part of its Clean Air Act Advisory Committee, a Subcommittee for Ozone, Particulate Matter and Regional Haze Implementation Programs ("Ozone-PM Subcommittee") to consider, among other issues, the ramifications of pollutant transport in terms of the design of regulatory structures and approaches. During the Subcommittee's deliberations, the nonattainment designation process itself came under scrutiny. Acknowledging the regulatory and economic burdens imposed on areas designated nonattainment where that designation might be caused, in whole or part, caused by pollutant transport from far upwind, it was proposed that identification of areas where NAAQS violations were monitored be decoupled from identification of the areas from which necessary emission reductions had to be obtained. ${ }^{81}$ The former areas were called Areas of Violation (AOVs), the latter were Areas of Influence (AOIs). In some instances, the borders of one for a particular pollutant might entirely overlap the borders of the other; in other cases, there might be a partial overlap; in still others, the AOV might be entirely separate from the AOI where the control measures would be implemented in order to attain the NAAQS in the downwind AOV. While, in the abstract, these concepts made sense, it was readily admitted that, in the real world, drawing the boundaries of AOVs and AOIs too precisely in order to avoid unnecessary control measures downwind might be infeasible from a technical point of view and also unduly delay the NAAQS implementation process. It was suggested that political or metropolitan area boundaries might have to be used, at least in part, in identifying AOIs and AOVs. ${ }^{82}$ The Ozone-PM Subcommittee itself never reached consensus on or made formal recommendations with regard to adoption of the AOV-AOI structure. ${ }^{83}$ Effectively, however, the regulatory efforts that the EPA subsequently undertook to deal with long-range transport of ozone and $\mathrm{PM}_{2.5}$ reflected the suggested differentiation between upwind areas causing NAAQS violations and downwind areas having to depend on upwind emission reductions in order to attain the NAAQS.

The legal foundation for the EPA's regulatory strategy for dealing with air pollution transport originating outside designated nonattainment areas is

81. 1998 FACA REPORT, supra note 26, at 3-4 to 3-6.

82. Id. at 3-5, 3-10 to 3-11.

83. Id. at ES-4. 
section 110(a)(2)(D) of the CAA. ${ }^{84}$ That provision requires that, in designing its SIP to attain the NAAQS within its own borders, a state must include controls on its own sources to prevent their emissions from contributing "significantly" to the nonattainment status of downwind areas in other states. Where a state fails to satisfy this statutory mandate to protect againstinterstate pollution, the EPA is authorized by section $110(\mathrm{k})(5)^{85}$ to require the state to revise its SIP to contain the necessary emission control measures (a so-called "SIP Call"); the failure to comply triggers EPA promulgation of a federal SIP to fill the gap. ${ }^{86}$ In this way, even if an area in one state is formally designated as attainment for a pollutant, it may have to institute controls to protect downwind states with regard to that pollutant. As a "backstop" to the SIP revision process, section 126 of the $\mathrm{CAA}^{87}$ authorizes a downwind state whose nonattainment status is created at least in part by an upwind state to petition the EPA to find that the prohibited interstate pollution is occurring and, for the sources identified as causing the problem, the EPA is empowered to impose necessary emission controls. ${ }^{88}$

In 1998, in reliance on section 110(k)(5), the EPA called for SIP revisions by twenty-two eastern states and the District of Columbia to reduce ozone season $\mathrm{NO}_{\mathrm{x}}$ emissions by approximately one million tons a year in the aggregate. ${ }^{89}$ Pennsylvania was included in this $\mathrm{NO}_{\mathrm{x}}$ SIP Call as both a "victim" of trans-boundary pollution from the mid-west and a cause of ozone farther east. The reductions called for did not insure that all interstate contribution to nonattainment would be eliminated. Rather, the benchmark for the required reduction was $\$ 2000$ per ton, representing, in the EPA's view, the limit of cost-effectiveness for required emission reductions. This benchmark was applied to a covered state's inventory of $\mathrm{NO}_{x}$, emission sources to arrive at the total $\mathrm{NO}_{\mathrm{x}}$ reduction required and, on this basis, the state was assigned a "cap" of allowable emissions that it could allocate among its $\mathrm{NO}_{\mathrm{x}}$ sources as it desired. However, since the SIP Call might not eliminate all interstate contribution to downwind nonattainment, which might also be caused by local

84. 42 U.S.C. $\$ 7410$ (a)(2)(D) (2005). With regard to regional haze, caused in part by ozone and PM emissions, the EPA has adopted a national program under sections 169A and B of the Clean Air Act, 42 U.S.C. $\S \S 7491-7492$ (2005), as well as section 110(a)(2)(D).

85. Section $7410(\mathrm{k})(5)$.

86. Section $7410(\mathrm{c})(1)$

87. Id. $\$ 7426$.

88. Section 7426(b), (c).

89. Finding of Significant Contribution and Rulemaking for Certain States in the Ozone Transport Assessment Group Region for Purposes of Reducing Regional Transport of Ozone, 63 Fed. Reg. 57,356 (Oct. 27, 1998). 
sources, for a state like Pennsylvania that was both subject to SIP Call emission reduction obligations and also contained some ozone nonattainment areas, the state's $\mathrm{NO}_{\mathrm{x}}$ cap might in some cases represent only part of the emission reductions included in its ozone attainment SIP; additional emission reductions might have to be adopted in order to attain the NAAQS.

The EPA also granted section 126 petitions filed by Pennsylvania and other states; the remedy granted was based on the $\mathrm{NO}_{\mathrm{x}}$ SIP Call methodology, though focusing on the control of specific sources and source groupings as required by section $126 .{ }^{90}$ In terms of state coverage, that EPA action was less extensive than the SIP Call and it was designed as a backstop in case implementation of the SIP Call did not go forward as planned. Pennsylvania was included among the states to implement section 126-required controls.

In Michigan Department of Environmental Quality v. EPA $A^{91}$ and Appalachian Power Co. v. EPA, ${ }^{92}$ the Court of Appeals for the District of Columbia Circuit upheld the legal interpretations implicated in the EPA's actions dealing with interstate pollution transport along with the Agency's underlying technical methodologies and determinations with a few, minor, exceptions.

When the challenges to the EPA's adoption of a new eight-hour ozone NAAQS and the new $\mathrm{PM}_{2.5}$ standard were finally put to rest, in $2002,{ }^{93}$ the EPA could begin the implementation process. On March 10, 2005, it issued a second SIP Call (known as the Clean Air Interstate Rule, or CAIR) relying in large part on the legal and methodological approaches of the first. ${ }^{94}$ CAIR focuses on $\mathrm{SO}_{2}$ and $\mathrm{NO}_{x}$ as precursors of $\mathrm{PM}_{2.5}$ and on $\mathrm{NO}_{x}$ as an ozone precursor. The coverage of this initiative extends to twenty-eight eastern states (including Pennsylvania) and the District of Columbia. As in the case of the $\mathrm{NO}_{x}$ SIP Call, the additional required reductions of these pollutants may by themselves eliminate nonattainment downwind or, in other cases, reduce, but not eliminate, the need for local control measures in designated nonattainment areas. In later proposing regulations to guide states in developing their $\mathrm{PM}_{2.5}$ SIPs, ${ }^{95}$ the EPA indicated that, in nonattainment areas

90. See, e.g., Findings of Significant Contribution and Rulemaking on Section 126 Petitions for Purposes of Reducing Interstate Ozone Transport, 65 Fed. Reg. 2674 (Jan. 18, 2000) (codified at 40 C.F.R. pts. 52, 97).

91. 213 F.3d 663 (D.C. Cir. 2000).

92. 249 F.3d 1032 (D.C. Cir. 2001).

93. See Am. Trucking Ass'ns v. EPA, 283 F.3d 355 (D.C. Cir. 2002).

94. See Rule to Reduce Interstate Transport of Fine Particulate Matter and Ozone (Clean Air Interstate Rule), 70 Fed. Reg. 25,162, 25,162-210 (May 12, 2005).

95. See Proposed Rule to Implement the Fine Particle National Ambient Air Quality Standards, 70 
subject to the CAIR, compliance with emission reduction obligations imposed on electric generating units as a result of CAIR would be considered Reasonably Available Control Technology (RACT) which is required of existing sources of nonattainment pollutants. ${ }^{96}$

With regard to both the $\mathrm{NO}_{\mathrm{x}}$ SIP Call and the CAIR, several aspects of those regulatory initiatives should be especially noted for current purposes. First of all, the nature of ozone and fine particulate formation and transport eliminated the need for the EPA to engage in pinpoint modeling of source and receptor. The precursors of both $\mathrm{O}_{3}$ (ozone) and $\mathrm{PM}_{2.5}$ are emitted from sources scattered over multi-state areas, travel downwind in highly diffuse patterns spread over hundreds of miles during which atmospheric chemistry transforms them into the pollutants of concern which remain to blanket large areas. Secondly, the state emission caps imposed by the EPA, which apply not only to existing but also new and modified sources, are, in part, the counterparts upwind to the offset requirements that apply downwind in nonattainment areas to prevent new source growth from canceling out emission reductions from existing sources. Thirdly, there is no LAER requirement that must be met by new or modified sources located in upwind areas subject to the SIP Call which are not themselves designated nonattainment for the pollutant of concern (ozone or $\mathrm{PM}_{2.5}$ ), unlike the situation that would exist if nonattainment area boundaries were drawn broadly to include all sources contributing to downwind nonattainment no matter how far away they might be from the point of NAAQS violation. This in itself may eliminate substantial over-control. ${ }^{97}$ Finally, the EPA has authorized emission trading among covered sources in both the $\mathrm{NO}_{x}$ SIP Call and the CAIR rule. Where trading is permitted by a state, a covered source can avoid reducing its own emissions if it is less expensive for it to purchase emission reductions from another source that can "cheaply" reduce its emissions more than required by law. Trading is justified because, from an economic theory perspective, it is a means to achieve the same level of aggregate emission reduction, no more and no less, at the least economic cost. The nature of ozone and fine particulate pollution is conducive to trading programs because what counts in terms of NAAQS attainment is not a reduction at a particular location, but the aggregate reduction of precursor emissions over a broad area.

Fed. Reg. 65,984, 65,984-66,067 (Nov. 1, 2005) (to be codified at 40 C.F.R. pts. 51-52).

96. Id. at 66,024 .

97. See supra note 55 and accompanying text. 


\section{The Nonattainment Designation Process and Southwestern PENNSYlVANiA}

On December 17, 2004, the EPA took final action on designations of areas for $\mathrm{PM}_{2.5}$ control. ${ }^{98}$ As of September 2005, there were thirty-nine $\mathrm{PM}_{2.5}$ nonattainment areas in the country, encompassing 208 counties, with a total population of over 88 million people. ${ }^{99}$ As it turns out, Allegheny County monitors some of the highest particulate levels in the Nation. Moreover, the configuration of the nonattainment boundaries in southwestern Pennsylvania is dictated by a variety of special factors and reflects a complexity not shared by many other areas in the east. As a consequence, a focus on the boundary drawing in and around Allegheny County offers an important case history illustrating not only the application of EPA's boundary guidance, but also its adjustment to deal with local conditions, in a context where section 107's designation process and the SIP Calls interact and a premium is placed on trying to avoid over-control of sources to the greatest extent feasible.

On February 25, 2004, the Pennsylvania Department of Environmental Protection (DEP) submitted to the EPA its recommended $\mathrm{PM}_{2.5}$ designations for the Commonwealth. ${ }^{100}$ It noted that nonattainment was a product of both local source emissions in urban areas and transport from large point sources, such as power plants. ${ }^{101}$ Figure 1 displays the 2000-2002 design values on which the DEP relied for its initial proposed designations.

98. Air Quality Designations and Classifications for the Fine Particles (PM2.5) National Ambient Air Quality Standards, 70 Fed. Reg. 944, 944-1019 (Jan. 5, 2005) (codified at 40 C.F.R. pt. 81).

99. See EPA, Particulate Matter (PM-2.5) Nonattainment Area Summary (Mar. 2, 2006), at http://www.epa.gov/oar/oaqps/greenbk/qnsum.html. The EPA revised some of the designations based on 2002-2004 data, reducing the number of nonattainment areas previously identified. See Air Quality Designations for the Fine Particles (PM2.5) National Ambient Air Quality Standards-Supplemental Amendments, 70 Fed. Reg. 19,844 (Apr. 14, 2005) (codified at 40 C.F.R. pt. 81).

100. Letter from Kathleen A. McGinty, Secretary, PA Dep't of Envtl. Prot., to Donald S. Welsh, Regional Administrator, EPA (Feb. 25, 2004) [hereinafter February Designation Proposal], at http:// www.dep.state.pa.us/dep/deputate/airwaste/aq/attain/recommendations.htm.

101. Id. at recommendations at 5 . 
FIGURE $1^{102}$

Figure 1 - Pennsylvania 2000 - 2002 PM 2.5 Annual Design Values Per County Based on Statistical Areas from 1999 Census Data (Report Dated June 30, 1999)
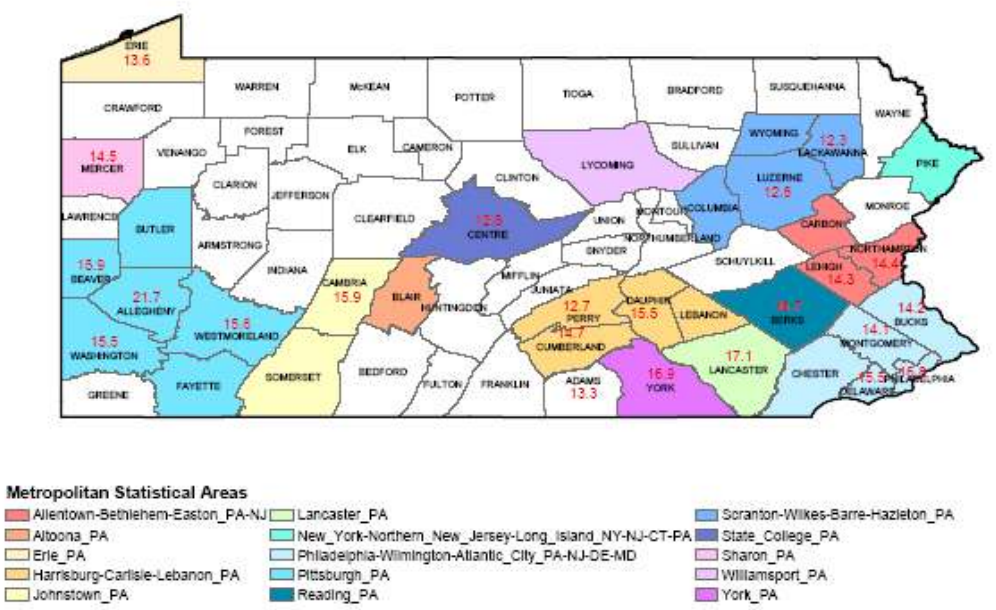

The Pittsburgh MSA included Allegheny, Beaver, Butler, Fayette, Washington, and Westmoreland counties. The EPA MSA/CMSA presumption suggested, therefore, that the six be included in a single nonattainment area given that air quality monitors located in parts of this broader area registered $\mathrm{PM}_{2.5}$ violations. However the DEPrecommended that only the four that monitored NAAQS violations be included: Allegheny (21.7 $\left.\mathrm{ug} / \mathrm{m}^{3}\right)$, Beaver $\left(15.9 \mathrm{ug} / \mathrm{m}^{3}\right)$, Washington $\left(15.5 \mathrm{ug} / \mathrm{m}^{3}\right)$, and Westmoreland $\left(15.6 \mathrm{ug} / \mathrm{m}^{3}\right)$ (Figure 2). ${ }^{103}$ Allegedly, emissions data, population density, and meteorology, suggested that Fayette and Butler Counties, with no air quality monitors, did not and would not contribute to nonattainment in the proposed four-county nonattainment area. ${ }^{104}$

102. Id. at recommendations at app. I, fig. 1 .

103. Id. at recommendations at 7 .

104. Id. at recommendations at 7-8. 
Figure 2: Pennsylvania’s Proposed Nonattainment Areas ${ }^{105}$

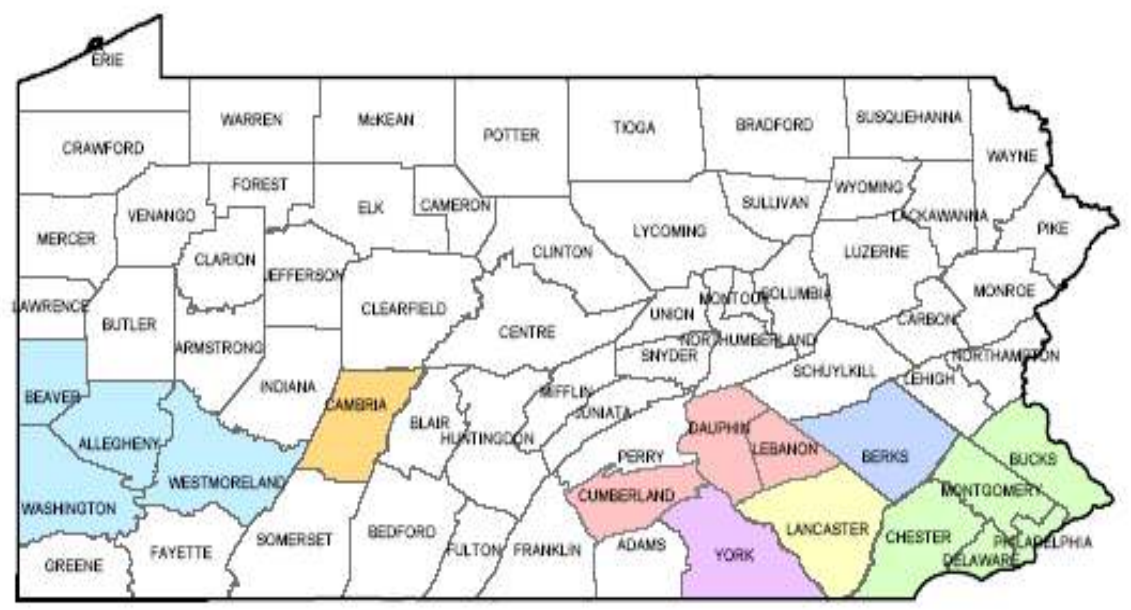

Proposed Nonattainment Areas

$\square$ Harisourg-Carlisle-Lebanon $\square$ Johnstown $\square$ Lancaster $\square$ Philadelphla $\square$ Pittbluargh $\square$ Reading $\square$ York

While public comments on the proposals argued that high emissions from nearby large power plants should be given more weight in the designation process even where the monitored air quality in the vicinity of the emission sources met the NAAQS, the DEP felt that extending nonattainment designations to encompass those point sources was not appropriate; that since the power plants contributed to regional transport, they should be regulated not as a consequence of the designation process, but at the regional or national levels (e.g., by a SIP Call). ${ }^{106}$ Not surprisingly, the Southwestern Pennsylvania Growth Alliance (SPGA) pointed out the economic impact of nonattainment designations in its comments, suggesting that the DEP either expand the boundaries of the nonattainment area to include upwind sources or draw very narrow boundaries for those areas (e.g., Liberty Borough) where the local component of $\mathrm{PM}_{2.5}$ was allegedly predominant. ${ }^{107}$ The DEP rejected

105. February Designation Proposal, supra note 100, at recommendations, app. I, fig. 3.

106. Id. at cmts. at 2 .

107. Id. at cmts. at 4 . 
the first SPGA proposal on the basis of a preference for reliance on the EPA's proposed CAIR rule; it also rejected the alternative, for the time being, until more data was collected. ${ }^{108}$

The EPA responded to the DEP's proposed designations on June 29, $2004 .{ }^{109}$ Unlike the DEP's initial proposal, the database for the EPA's action included 2001-2003 air quality data where the design values for Allegheny, Beaver, Washington, and Westmoreland counties were adjusted to 21.2, 16.0, 15.5 and $15.5 \mathrm{ug} / \mathrm{m}^{3}$ respectively. ${ }^{110}$ No monitoring data was available from Armstrong, Butler, Fayette, Greene, or Lawrence counties (though the estimated air quality in all five exceeded the annual NAAQS of $\left.15.0 \mathrm{ug} / \mathrm{m}^{3}\right) .{ }^{111}$ The EPA expanded the proposed nonattainment area to include all of those counties except Fayette. Butler was added based on the MSA presumption and Lawrence County, which was included in the "combined statistical area" in 2003, was added based on EPA's judgment that its emissions contributed to nonattainment in the Pittsburgh MSA. In the case of Armstrong and Greene, the inclusion was allegedly called for, at least in part, because of the large power plants located there (Armstrong and Keystone in Armstrong County, and Hatfield's Ferry in Greene), and the fact that the counties were contiguous to the Pittsburgh MSA (Greene borders Washington County and Armstrong sits adjoining Butler, Allegheny, and Westmoreland counties) whose monitored NAAQS violations were, in EPA's view, caused in part by the power plant emissions. ${ }^{12}$ The EPA invited the DEP to submit further recommendations suggesting how to narrow the nonattainment designation in those "power plant counties" to encompass only parts of the counties, therefore reducing the amount of over-control that might result from too broad a designation. ${ }^{113}$

108. Id. at cmts. at 4-5.

109. Letter from Donald S. Welsh, Regional Administrator, EPA, to Edward G. Rendell, Governor, State of PA (June 29, 2004) [hereinafter EPA Designation Response], at http://www.epa.gov/ pmdesignations/documents/04Recommendations/3/s/Pennsylvania_R.pdf.

110. Id. at enclosure B (Table: Summary of Factor 2: Air Quality Pittsburgh Pa MSA).

111. $I d$.

112. Id. at enclosure B.

113. $I d$. at enclosure A. In considering emissions and air quality with regard to adjacent areas under the first of the nine factors listed in its 2003 boundary guidance, the EPA developed a controversial "weighted emissions score" that purportedly valued the effect of direct emissions of $\mathrm{PM}_{2.5}$ and its precursors that contributed to "urban excess" $\mathrm{PM}_{2.5}$ concentrations at monitor sites, that is to say, the amount of urban particulate matter left after subtracting the regional component. $I d$. at enclosure C. The EPA also relied on speciation monitors to draw some conclusions regarding likely sources of NAAQS violations. 
Replying to the EPA in August 2004, the DEP objected to the proposed designation of the "power plant counties." "114 In its view, their contribution to nonattainment was more appropriately handled via control of transported pollution. ${ }^{115}$ The rationale for this objection was clear: entire counties would be subject to nonattainment regulatory requirements unnecessarily, in the Commonwealth's judgment

Moreover, in its August 2004 letter to the EPA, the DEP suggested the creation of two small separate nonattainment areas within Allegheny County, that is, nonattainment areas within a larger nonattainment area, based on more recent analysis of monitoring data and meteorology. ${ }^{116}$ Allegedly, there were unique local $\mathrm{PM}_{2.5}$ sources impacting on the air quality monitors in three locations, Liberty Borough, Clairton, and North Braddock. ${ }^{117}$ This was not an alternative explicitly confronted by the EPA's boundary guidance memorandum of April 2003.

What potential problem suggested to the Commonwealth that it should propose a subdivision of an area that would in all events be designated nonattainment? As Figure 3 indicates, a variety of monitors within Allegheny County recorded $\mathrm{PM}_{2.5}$ violations ( $>15 \mathrm{ug} / \mathrm{m}^{3}$ for an annual average) during 2003. The EPA's MSA boundary presumption, ${ }^{118}$ along with only one monitored violation within the county, insured that the entire county would be included in the MSA nonattainment area. If that MSA area were not subdivided, it would be assigned an attainment date ranging from five to ten years following the designation, depending on "the severity of nonattainment and the availability and feasibility of pollution control measures." 119

114. August McGinty Letter, supra note 21, at 2.

115. Id. at enclosure at 2, 25-26.

116. Id. at enclosure at 1 .

117. $I d$.

118. See supra text accompanying notes $36-56$.

119. 42 U.S.C. $\$ 7502(a)(2)(A)(2005)$. 
FiguRe $3^{120}$

2003 PM 2.5 Design Values for Pennsylvania and Surrounding Areas Based on the Annual $\mathrm{PM}_{2.5}$ Standard of $15 \mu \mathrm{g} / \mathrm{m}^{3}$

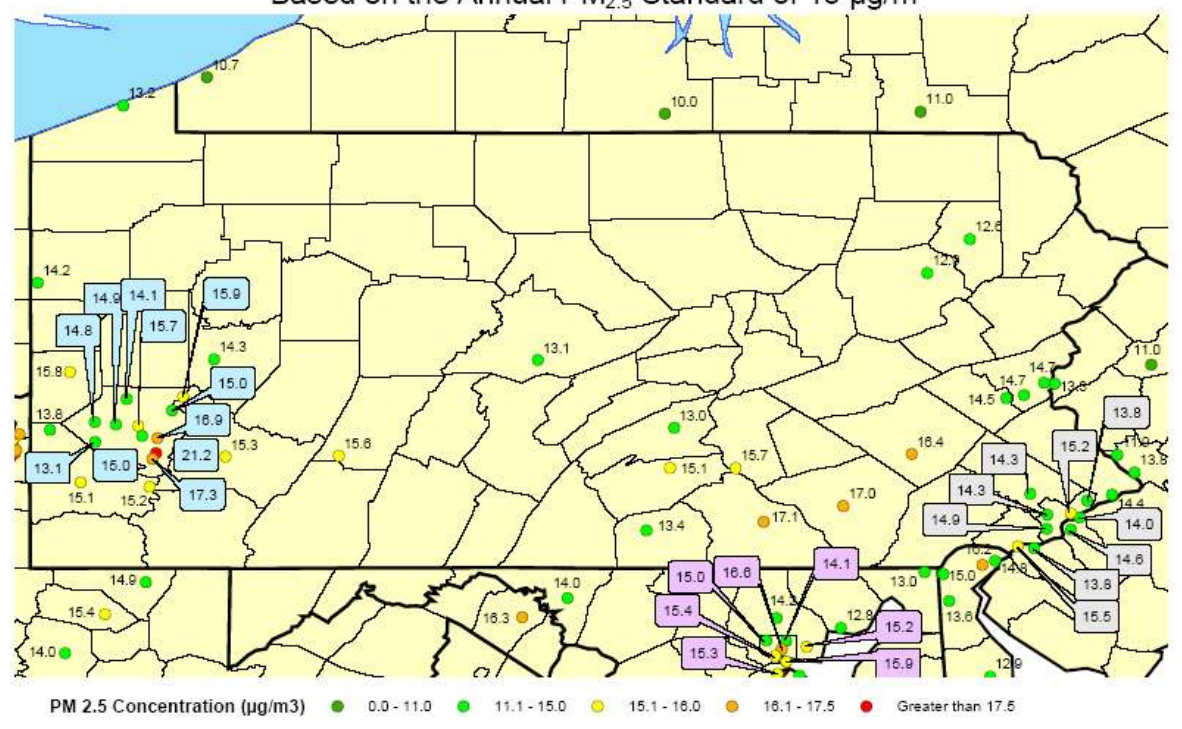

The foundational assumption of the DEP in suggesting a subdivision of Allegheny County was that it would likely take the two small proposed nonattainment areas within the county longer to attain the NAAQS because of the nature of the local emission problem. ${ }^{121}$ If the attainment date assigned to the Pittsburgh MSA were based on the $21.2 \mathrm{ug} / \mathrm{m}^{3}$ design value recorded in one of these small proposed subdivisions (Liberty Borough), the entire MSA would be saddled with LAER and offset requirements until that monitor recorded air quality at or below the NAAQS level. ${ }^{122}$ If, on the other hand, the MSA was subdivided, an earlier attainment date could be assigned to the single nonattainment area that surrounded the two proposed smaller ones. If, as expected, the EPA's SIP Calls, its new car and truck emission controls (some slated for implementation by 2007), and any needed local controls reduced the monitoring values within the broader MSA to, or below, NAAQS levels by its earlier attainment date, most of the Pittsburgh MSA could be re-

120. August McGinty Letter, supra note 21, at app. I, fig. 4.

121. Id. at enclosure at 1.

122. In all events, RACT/RACM requirements would have to be met in both nonattainment areas and, even following the attainment date(s) assigned, would have to be maintained to prevent backsliding to nonattainment. 
designated to attainment ${ }^{123}$ and escape at least LAER and offset requirements for new and modified sources that might locate or operate in the area subsequent to the re-designation. ${ }^{124}$ Meanwhile, the smaller included nonattainment areas could make their own progress toward attainment and their failure to achieve it would not result in continued subjection of the rest of the MSA to nonattainment controls.

In short, the subdivision of the MSA nonattainment area into two or more nonattainment areas was a strategy proposed to avoid the potential for overcontrol of sources if one part of the broader area moved at a faster pace toward attainment than the other(s). To the extent the earlier attainment date for most of the MSA would be based in part on the CAIR rule, that is to say, upwind emission reductions, the Pittsburgh MSA would be a textbook case of an AOV benefiting from control measures implemented in a separate AOI. The first emission reductions under CAIR were expected within the 2009-2010 timeframe (assuming litigation did not delay implementation) and might, along national and local emission reductions, be sufficient to bring attainment within the presumptive five year deadline. ${ }^{125}$

Of course, the DEP's strategy would fall short of its goal to the extent that emissions from the two proposed small areas were in fact significant contributors to nonattainment in other parts of the Pittsburgh MSA. In that event, failure to impose early and stringent controls in the Liberty and Braddock areas could insure that the MSA would maintain its nonattainment status beyond its attainment date.

In order to avoid the consequences that would be caused by accepting a distant attainment date for the Pittsburgh MSA as a whole, there was another option. In lieu of the DEP subdividing Allegheny County, the Allegheny County Health Department, which is responsible for SIP design and implementation within the county, could impose stringent local controls on the stationary emission sources allegedly causing the high monitor readings and require compliance by them no later than the earlier date when the other monitors in the MSA were expected to show attainment. The local economic burden of such an approach in terms of job losses if a facility closed or cut

123. 42 U.S.C. $\$ 7407(d)(3)(E)$ (2005) (redesignation to attainment).

124. Even upon redesignation, however, RACT controls on existing sources necessary to attain the NAAQS in the broader MSA would have to be maintained to prevent "backsliding" to nonattainment unless different controls on those or other sources in the area could be substituted on the basis that they would maintain compliance with the NAAQS following redesignation.

125. $\mathrm{PM}_{2.5}$ SIPs are due no later than April 2008 and a five year attainment date, measured from the date of designation, would fall in April 2010. Given that attainment is determined based on three years of emission data, CAIR reductions might have limited impact unless implemented earlier than required. 
back operations presumably made this option less desirable than the subdivision of Allegheny County into separate nonattainment areas.

Indeed, there was precedent for designation of a smaller nonattainment area containing Liberty Borough and the fears of delayed attainment had some basis. During the 1990s, a monitor located across from US Steel's Clairton Coke Works registered $\mathrm{PM}_{10}$ violations for several years after the rest of the county met the EPA's NAAQS for that pollutant. At that time, the designated nonattainment area was limited to the city of Clairton and the boroughs of Liberty, Glassport, Port Vue, and Lincoln.

It was emissions from this same industrial facility, the largest metallurgical coke plant in the United States, which is located in the Monongahela River valley with high bluffs to the northeast in which direction the prevailing wind blows, that suggested the need for one of the two proposed small $\mathrm{PM}_{2.5}$ nonattainment areas. ${ }^{126}$ The Liberty monitor recorded the highest reading in the county (indeed, in the entire northeast United States) of 21.2 $\mathrm{ug} / \mathrm{m}^{3}$; the Clairton monitor was next at $17.3 \mathrm{ug} / \mathrm{m}^{3}{ }^{327}$ In North Braddock, the site of the historic Edgar Thomson Works of US Steel, the monitor recorded the third highest reading in the county of $16.9 \mathrm{ug} / \mathrm{m}^{3} .{ }^{128}$ Monitors surrounding these three showed pollutant levels at or only slightly above the $15.0 \mathrm{ug} / \mathrm{m}^{3}$ annual standard. ${ }^{129}$ The DEP and the Allegheny County Health Department prepared an analysis of available data suggesting that the three high monitor readings were arguably traceable to the nearby industrial facilities. They focused on regional average monitor readings in comparison to the readings at the three monitors, wind directional data, the diurnal cycle of $\mathrm{PM}_{2.5}$ emissions at various monitors, and speciation of the particle material at various locations. ${ }^{130}$ The proposed Liberty nonattainment area consisted of five municipalities (the city of Clairton, borough of Glassport, Liberty Borough, borough of Lincoln, and Port Vue Borough) (Figure 4), the same borders used for the former $\mathrm{PM}_{10}$ nonattainment area. The proposed North Braddock nonattainment area consisted of two municipalities (Braddock Borough and North Braddock Borough) (Figure 5).

126. See August McGinty Letter, supra note 21, at enclosure at 1, 18-19.

127. Id. at enclosure at 15 .

128. Id.

129. Id.

130. Id. at enclosure at 16-23. 
FIGURE $4^{131}$

Proposed Liberty Nonattainment Area

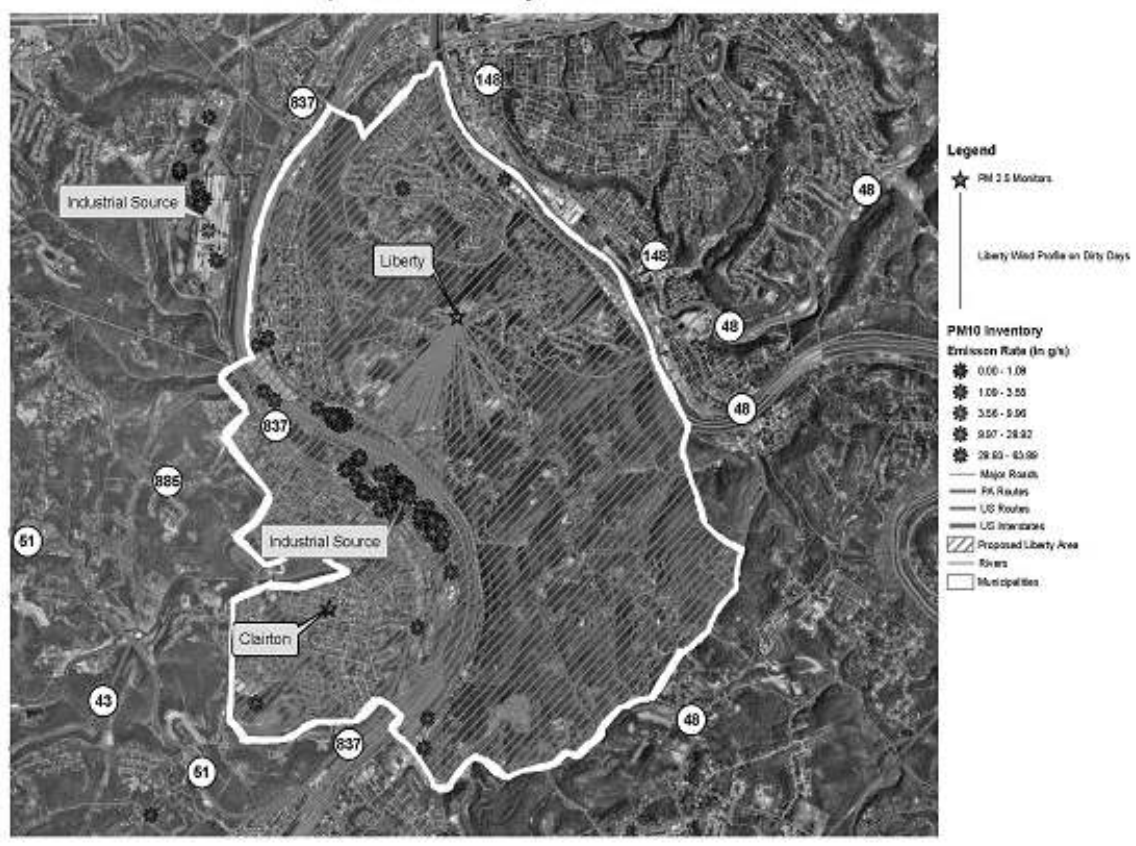

131. August McGinty Letter, supra note 21, at app. IV, fig. 12. 


\section{FIGURE $5^{132}$}

\section{Proposed North Braddock Nonattainment Area}

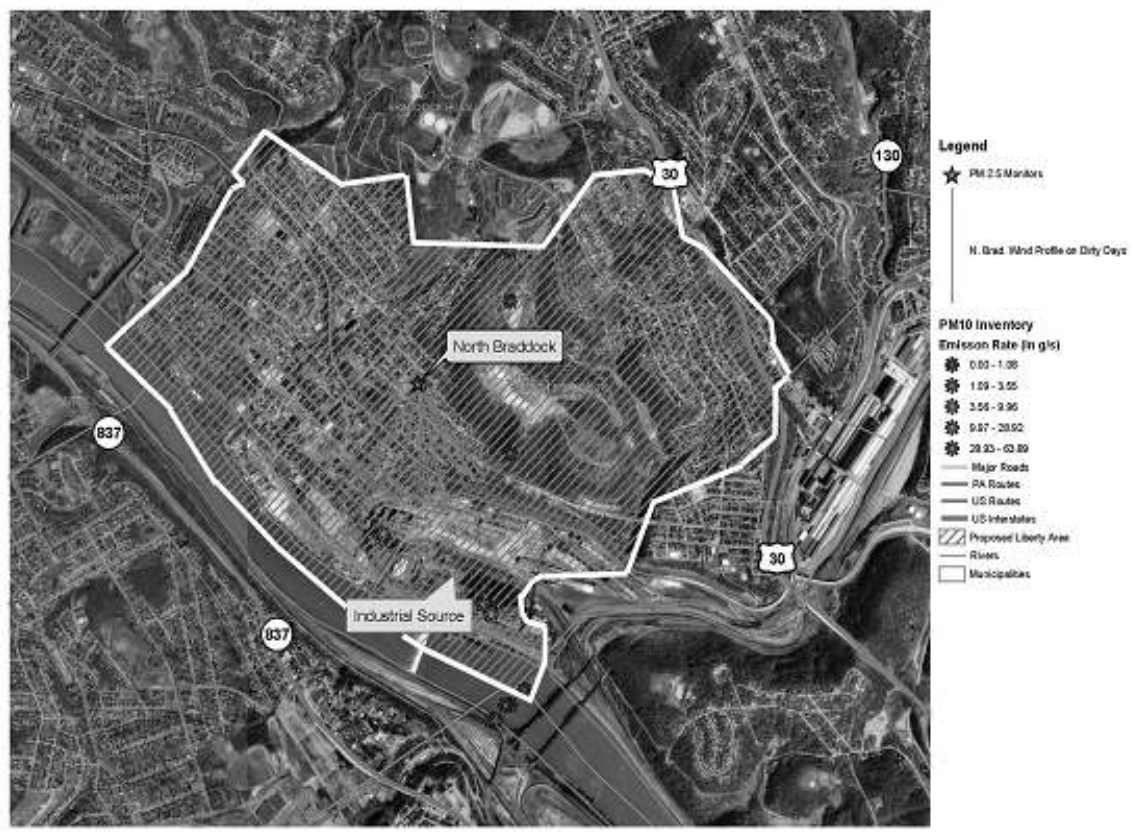

Finally, the DEP's August 2004 letter to the EPA objected to the inclusion of Butler and Lawrence counties in the nonattainment area on the basis that they lacked significant sources of emissions and did not contribute to particulate levels in the rest of the Pittsburgh MSA. ${ }^{133}$ With regard to Lawrence, the only significant emission source was a power plant.

In November, the DEP followed up the EPA's suggestion to limit nonattainment areas in "power plant counties" to smaller areas including the plants. ${ }^{134}$ Figure 6 shows the proposed new borders of these areas, which were drawn to attach to the borders of the Pittsburgh MSA.

132. Id. at app. IV, fig. 14 .

133. Id. at enclosure at 26-27.

134. Letter from Kathleen A. McGinty, Secretary, PA Dep't of Envtl. Prot., to Donald S. Welsh, Regional Administrator, EPA (Nov. 16, 2004), at http://www.dep.state.pa.us/dep/deputate/airwaste/aq/ plans/plans/designation/signed_cover_ltr_addl.pdf. 
FIGURE $6^{135}$

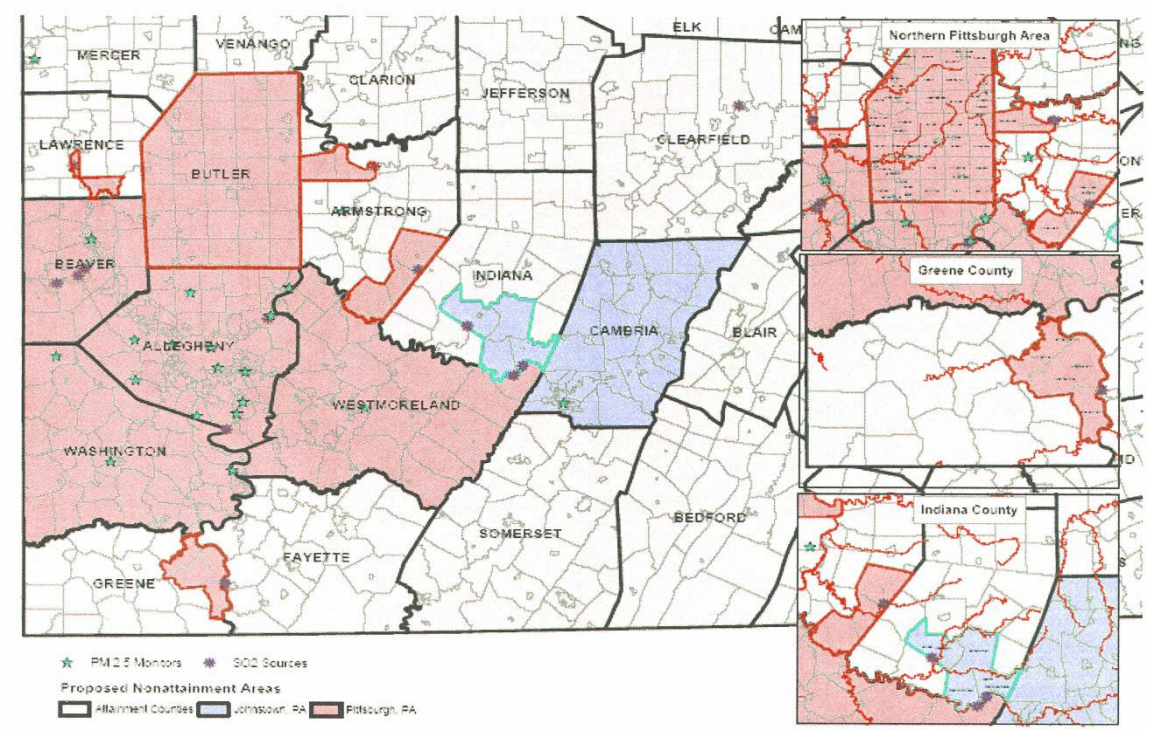

In December 2004, the EPA took final action on $\mathrm{PM}_{2.5}$ designations, making them effective on April 5, 2005. With regard to the Pittsburgh MSA, the nonattainment area (called Pittsburgh-Beaver Valley) included five of the six MSA counties (Allegheny, Beaver, Butler, Washington, and Westmoreland, but not Fayette). ${ }^{136}$ Accepting the DEP's analysis, however, the EPA designated one of the two proposed subdivisions of Allegheny County, the Liberty/Clairton area, as a separate nonattainment area. ${ }^{137}$ Even if emissions from that area contributed to nonattainment in the rest of the Pittsburgh MSA, neither section 107(d) nor the EPA's boundary guidance restricted the EPA's power to subdivide the nonattainment area. ${ }^{138}$

135. Id. at enclosure.

136. Integrated Policy \& Strategies Group, EPA, Technical Support for State and Tribal Air Quality Fine Particle (PM2.5) Designations 6-83, at http://www.epa.gov/pmdesignations/ documents/final/TSD/Ch6.pdf.

137. $I d$. at 6-90 to 6-91.

138. First, the language of section 107(d) regarding designating "nearby" areas contributing to nonattainment appears to deal with the situation where the "nearby" area does not monitor nonattainment, which is not the case in the Liberty area. Second, the provision merely mandates that the EPA designate the "nearby" area as nonattainment; there is no language suggesting that the agency must necessarily include it as part of the nonattainment area where NAAQS violations are monitored. 
With regard to the three "power plant counties," the EPA went even beyond what the DEP proposed; it created "islands" of nonattainment surrounding the power plants of concern in Armstrong (2), Greene (1), and Lawrence (1) counties, without the "land bridges" proposed by the DEP to connect the "islands" to the nearby Pittsburgh-Beaver Valley Nonattainment Area. ${ }^{139}$ This refinement eliminated nonattainment controls in most parts of counties adjoining the MSA where NAAQS violations had not been identified; township boundaries for the small power plant nonattainment islands were employed. Figure 7 shows the current configuration and location of the Pittsburgh-Beaver Valley and Liberty/Clairton Nonattainment Areas.

139. Integrated Policy \& Strategies Group, EPA, supra note 136, at 6-90. In doing so, the EPA continued to adhere to its "weighted emissions score" to identify adjoining counties deemed to contribute to $\mathrm{PM}_{2.5}$ violations in the MSA. Id. at chs. 3, 4, 5 . 


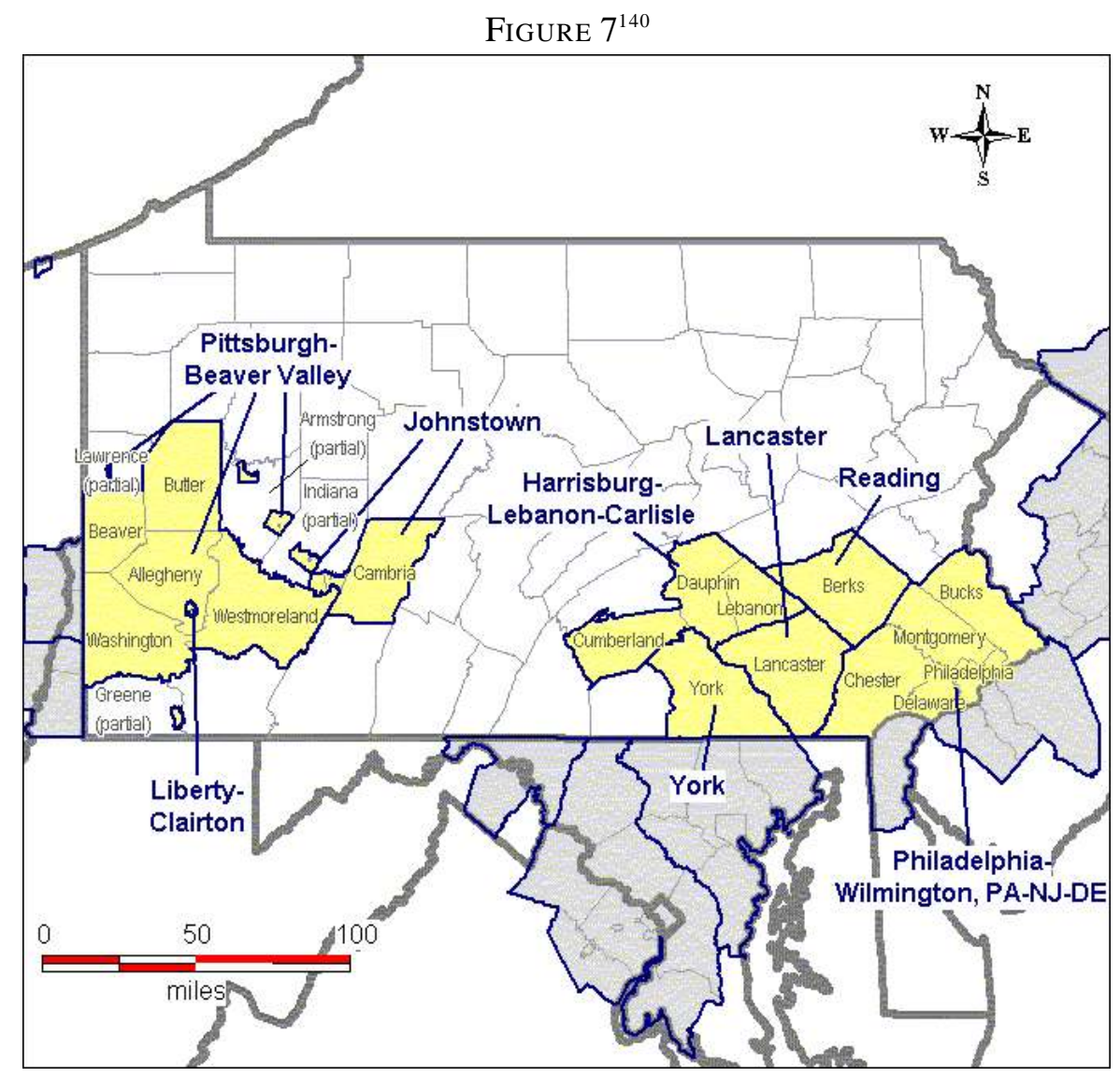

Briefly stated, in accordance with section 107(d) of the CAA, the EPA has dealt with local-scale pollutant transport within the Pittsburgh MSA by including not only entire counties within the MSA with monitored NAAQS violations, but also "nearby" areas, specifically Butler County and various "nonattainment islands" tightly drawn around power plants located in Armstrong, Greene and Lawrence counties, that do not themselves have monitored NAAQS violations. Long-range transport has been dealt with, not through the designation process, but through regulatory initiatives like the CAIR rule which place significant emission reduction burdens far upwind even when those areas do not monitor $\mathrm{PM}_{2.5}$ nonattainment themselves,

140. EPA, Pennsylvania PM 2.5 Designations Map, at http://www.epa.gov/pmdesignations/ states/Pennsylvania.htm (last visited June 24, 2006). 
thereby reducing the need for at least some local controls in the PittsburghBeaver Valley area that might otherwise be required (the AOI-AOV concept $\left.^{141}\right)$. Finally, in one small area allegedly dominated by locally generated pollution, the EPA has departed from its MSA boundary presumption to isolate another type of nonattainment "island," which is an entirely separate nonattainment area, that may take more time and effort to achieve the NAAQS and that, without separate recognition, could singlehandedly hold the rest of the broader MSA in nonattainment status. In these various ways, the EPA has attempted to craft a regulatory "map" that limits as much as feasible, considering technical and other restrictions, the need to impose emission controls on existing sources ${ }^{142}$ and LAER and offset requirements where they may not be necessary for attainment of the $\mathrm{PM}_{2.5}$ NAAQS.

\section{Concluding Observations: The Choices Remaining}

With the designation process completed for the time being,${ }^{143}$ two primary tasks confront the Commonwealth and the Allegheny County Health Department, prior to 2008 when the $\mathrm{PM}_{2.5}$ SIPs must be submitted to the EPA. First of all, they must identify those local control measures (RACT/RACM or beyond) necessary to bring the two nonattainment areas in southwestern Pennsylvania into compliance with the $\mathrm{PM}_{2.5}$ NAAQS. ${ }^{144}$ Secondly, they must propose attainment deadlines to the EPA for those areas. What choices are available with regard to the "power plant counties" and the Liberty/Clairton nonattainment area in particular?

141. See supra notes $81-83$ and accompanying text.

142. Technically speaking, since the Pittsburgh-Beaver Valley area is nonattainment, the CAIR rule cannot as a matter of law eliminate the need for local sources to comply with RACT/RACM, but it can reduce the need for additional local controls.

143. The EPA has proposed to revise its particulate standards to make them more stringent, an action that may trigger another round of PM designations in the upcoming years. See Transition to New or Revised Particulate Matter (PM); National Ambient Air Quality Standards (NAAQS), 71 Fed. Reg. 6718 (proposed Feb. 9, 2006).

144. It remains to be seen how stringently the EPA will interpret the RACT/RACM requirement for $\mathrm{PM}_{2.5}$. It has proposed several options, some of which permit RACT to be determined based on the need for reductions to attain the NAAQS. See Proposed Rule to Implement the Fine Particle National Ambient Air Quality Standards, 70 Fed. Reg. 65,984, 66,016-21 (Nov. 1, 2005) (to be codified at 40 C.F.R. pts.51-52).

Given the fact that many of the areas included in the Pittsburgh-Beaver Valley and Liberty/Clairton Nonattainment Areas have been nonattainment for ozone and PM in the past, many sources have installed what were considered RACT controls. Depending on how the EPA defines RACT, additional controls for $\mathrm{PM}_{2.5}$ attainment could be considered "beyond" RACT, but still required for attainment. 
With regard to the four power plants contained within the nonattainment islands to the north, east, and south of Allegheny County, the EPA's inclusion of these sources within the Pittsburgh-Beaver Valley Nonattainment Area on the basis of their contribution to the Pittsburgh MSA's ambient air quality ${ }^{145}$ means that they will be subject to RACT requirements. However, if they are regulated by the DEP under the CAIR rule, the EPA may consider the emission limitations thus imposed as RACT, at least if the DEP opts entirely to satisfy its CAIR obligations through regulation of electric generating units. ${ }^{146}$ But, given these plants' assumed local contribution to nonattainment in the Pittsburgh MSA, it would seem to be difficult to justify their participation in any emission trading regime set up under the CAIR rule that might permit them to avoid controls through purchasing emission reductions from other CAIR-regulated sources, perhaps hundreds of miles away. ${ }^{147}$

With regard to the Liberty/Clairton Nonattainment Area, the choices may be difficult indeed. While the DEP and the County could propose a longer attainment date for that area than for the Pittsburgh-Beaver Valley Nonattainment Area, it is not required by law to do so. When subdivision of Allegheny County into several nonattainment areas was proposed, various environmental groups noted the inequity of allowing the economically depressed Monongahela River areas, still reeling from the precipitous decline of the steel industry, to continue to suffer the adverse health effects of particulate pollution for years longer than the more affluent inner city areas and suburbs of Pittsburgh. ${ }^{148}$ This is clearly a consideration that should weigh heavily in the decision-making calculus employed by the Commonwealth and Allegheny County in setting attainment dates.

On the other hand, there will be substantial political pressures to propose a longer attainment date for Liberty/Clairton to accommodate a slower pace of cleanup for industries located there, particularly US Steel's Clairton Coke Works. Over the last thirty-six years, faced with significant clean-up obligations under the Clean Air Act and the prospect (or actuality) of

145. See supra notes $103-04$ and accompanying text.

146. See supra notes $95-96$ and accompanying text.

147. The EPA's willingness to consider CAIR as RACT for covered electric generating units is rooted in the trading program's ability to insure cost-effective achievement of the imposed emission caps. See Proposed Rule to Implement the Fine Particle National Ambient Air Quality Standards, 70 Fed. Reg. at 66,025 ("Thus, the imposition of source-specific RACT on EGUs covered by CAIR would not reduce total emissions, but would likely achieve the same total emission reductions in a more costly way.").

148. Letter from RachelFilippini, Executive Director, Group Against Smog and Pollution, to Makeba Morris, Branch Chief of Air Quality Planning, and Linda Miller, PM2.5 Coordinator, Region III EPA (Nov. 4, 2004) (in possession of author). 
governmental and citizen enforcement, that facility has already reduced its air emissions to the point that, in the early 1990s, the EPA considered it one of the best controlled coke plants in the United States and used it as a model for the Agency's Maximum Achievable Control Technology (MACT) standards for toxic pollutants under section 112 of the CAA. ${ }^{149}$ The Clairton plant's huge size and location, along with the apparent fragility of the domestic steel industry, will create additional challenges for the regulators in crafting an effective control strategy that can bring the Liberty/Clairton area into attainment on a schedule similar to that applicable to the rest of Allegheny County.

While the nonattainment area boundary drawing is now complete for the existing $\mathrm{PM}_{2.5}$ standard, the implementation process for that NAAQS is just beginning and promises to present even more difficult issues of science, law and politics. And, as if those challenges were not enough, the upcoming revision of the PM standards ${ }^{150}$ will add still further complications and, within several years, may return us to where we started-the nonattainment designation process.

149. 42 U.S.C. $\$ 7412$ (2005).

150. See National Ambient Air Quality Standards for Particulate Matter, 71 Fed. Reg. 2620 (Jan. 17, 2006) (to be codified at 40 C.F.R. pt. 50). 